\title{
REMEDIES UNDER ARTICLE TWO OF THE UNIFORM COMMERCIAL CODE: AN AGENDA FOR REVIEW
}

\author{
JoHN A. SEBERT, JR.†
}

The Uniform Commercial Code has been with us, in one form or another, for over a quarter century, ${ }^{1}$ and its genesis goes back even further, to about $1940 .^{2}$ The task of preparing a uniform and unitary commercial code was a monumental one, and that task was carried out with consummate skill by Karl Llewellyn and his associates. There is little doubt that this effort was one of the most complex codification processes in the history of American law, and the result, on the whole, has been outstandingly successful. ${ }^{3}$

The Code, however, has not remained static during this quarter century. A complete review of article 9, which covers secured transactions, was conducted under the auspices of the Code's Permanent Editorial Board, and the result was the promulgation of revised article 9 in 1972.4 Article 8, on investment securities, was revised substantially in $197 \%$, primarily to deal with the increasing

$\dagger$ Professor of Law, University of Tennessee. A.B. 1964, J.D. 1967, University of Michigan. I would like to thank Professor Robert S. Thompson of the University of Southern California for his helpful comments on a draft of this article. I also note my appreciation for the excellent research assistance of Jeffrey L. Jernegan, Esq. during the early stages of this project.

1 Pennsylvania was the first jurisdiction to adopt the Code, enacting an early version in 1953. Uniform Commercial Code, P.L. No. 1, 1953 Pa. Laws 3 (current version at 13 PA. Cons. Stat. AnN. $\$ 1101-9507$ (Purdon Supp. 1980)); see J. WHITE \& R. SumMans, HaNDBOOK OF THE LAW UNDER THE UNIFORM COMMERciar. CoDe $\$ 1$, at 4 (2d ed. 1980); Schnader, Pennsylvania and the Uniform Commercial Code, 37 TEMr. L.Q. 265 (1961).

2 A proposal to draft a comprehensive commercial code, rather than revise the numerous separate uniform acts then covering commercial practice, was first adopted by the National Conference of Commissioners on Uniform State Laws in 1940. Schnader, A Short History of the Preparation and Enactment of the Uniform Commercial Code, 22 U. MLAma L. Rev. 1 (1967). On the history of the Code, see generally id. 2.

${ }^{3}$ Forty-eight states, the District of Columbia, and the Virgin Islands enacted the Code in the ten-year period between 1957 and 1967. Id. 10. Now all the states except Louisiana have enacted the Code, 1977 U.C.C. Rep. Serv. (Callaghan) State Correlation Tables (1979), and even Louisiana has enacted articles $1,3,4,5$, 7 , and 8, but not article 2, LA. Rev. Stat. ANN. $\$ \$ 10: 1-101$ to :8-501 (West Supp. 1981).

4 Review Commitee for Article 9 of the Uniform Commercial Code, Permanent Edtortal board for the Uniform Commercial Code, Final REPORT (1971). The best overview of the 1972 changes in article 9 is found in Coogan, The New UCC Article 9, 86 HARv. L. Rev. 477 (1973). 


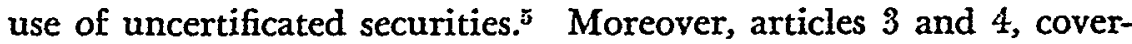
ing negotiable instruments and bank deposits and collections, are presently under review by a committee of the Permanent Editorial Board, principally to consider the implications of electronic data processing for those articles. ${ }^{6}$

No such intensive review has been undertaken with respect to the sales provisions of article $2,{ }^{7}$ although this is the longest and the oldest part of the Code. ${ }^{8}$ It is now time to undertake a comprehensive review of this article similar to that previously conducted of article 9. While the reasons for urging this reconsideration are different from those underlying the 1972 revision of article 9,9 other factors make review of article 2 particularly appropriate at this time. First, work on the Restatement (Second) of Contracts has recently been completed, ${ }^{10}$ and it seems sensible to apply the

5 Peraranent Edtroriat Bosta for the UntForm Comamerctax Code, Próposed Reviston of Article 8 and Related Changes in Other Articles Recom-

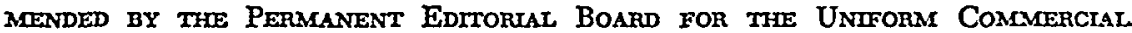
CODE (1977). 8. Id.

B Id. $\mathrm{x}$. The committee also is considering possible further changes in article

7 In 1966, the Permanent Editorial Board recommended a few changes to article 2. For example, they deleted the "lien creditor" language from $\$ 2-702(3)$ to eliminate the risk that a seller reclaiming goods from an insolvent buyer would lose to the buyer's trustee in bankruptcy under the trustee's powers as a lien creditor. Another change added alternatives to $\$ 2-318$ permitting states to expand the extent to which warranties extend to persons other than the immediate purchaser. See Permanent Edtrorual Board for the Uniforar Comemerctal Code, REPORT No. 3 (1967) [hereinafter cited as Report No. 3].

8 The major work on article 2 was completed in the 1940's and was given final approval at a joint meeting in May 1951. See Peters, Remedies for Breach of Contracts Relating to the Sale of Goods Under the Uniform Commercial Code: A Roadmap for Article Two, 73 YALE L.J. 199, 200 (1963); Project, The Uniform Commercial Code and Contract Law: Some Selected Problems, 105 U. PA. L. Rev. $836,837 \mathrm{n} .2$ (1957). The revisions in article 2 between the 1949 draft and the 1962 Official Text were relatively minor. See 6 U.C.C. REP.-Dig. (MB) $\$ \$ 2-101$ to -809 (1981) (including drafting history to each section).

9 The revisions of article 9 were prompted by the epidemic of nonuniform enactments of article 9 in the mid-1960's which seriously eroded the goal of uniformity. By 1966, 337 nonuniform, nonofficial amendments to 47 of the 54 sections of article 9 were made by as many as 30 jurisdictions. See REPORT No. 3, supra note 7 , at $x$.

No such rash of nonuniform amendments to article 2 has been adopted. Through 1966, the Permanent Editorial Board had commented on a total of 88 nonuniform amendments or deletions respecting article 2, but many of these revisions had been very minor. See Report No. 3, supra note 7; Permanent Edrtoriax. BonRd for the Uniform Commercial Code, Report No. 2 (1965).

10 The last chapter of the Second Restatement, the remedies chapter, finally appeared in tentative draft form in the spring of 1979. See RESTATENENT (SECOND) of Contracts $\$ \S 358-399$ (Tent. Draft No. 14, 1979). The final product has just been published. See Restatenient (Second) of Contracts (student ed. 1981). 
additional insights gained during that process to article 2. Second, after extensive experience under this article in many jurisdictions, scholarly commentary and judicial decisions have revealed difficulties in a number of areas that can be alleviated by revisions of specific provisions.

Although I am suggesting an overall review of article 2, I am not asserting that the sales article contains pervasive conceptual difficulties that would necessitate a significant restructuring of the article. ${ }^{11}$ On the contrary, article 2 is probably the best-conceived and best-drafted part of the Code. In most respects, it has been astoundingly successful. For example, the Code's risk of loss provisions, ${ }^{12}$ focusing on the realities of commercial behavior rather than the illusive concept of title, seem to have succeeded in clarifying that previously murky area of the law; at least there now is little litigation or critical commentary concerning the risk of loss provisions. ${ }^{13}$ More importantly, Llewellyn's concept of a code with open-ended provisions that leave courts substantial flexibility to resolve disputes based upon reasonable commercial practices and the facts of a particular case has certainly been vindicated. Standards based upon reasonableness, course of dealing, and usage of trade ${ }^{14}$ are workable. While such standards produce uncertainty, that uncertainty merely mirrors reality, and I neither make nor imply any suggestion that these open-ended standards be jettisoned

11 On the whole, of course, the 1972 revision of article 9 also did not involve a major restructuring or an alteration of philosophy. The treatment of fixtures and of perfection when collateral moves from one jurisdiction to another was substantially revamped, but many of the other revisions were relatively minor clarifying changes. See REview CoMMitTeE For ARTICLE 9 OF THE UNIFORM COMMERCIAI Code, Permanent Editorial Boafd for the Untforat Commercial Code, Final Report 195-96 (1971); Coogan, supra note 4; Davenport, Default, Enforcement and Remedies Under Revised Article 9 of the Uniform Commercial Code, 7 VAr. U.L. REv. 265 (1973).

12 U.C.C. $\$ \$ 2-509,-510,-613$ (1977). All further citations to the UCC refer to the latest official version of the Code, unless otherwise indicated.

13 One study shows that, in Califormia, New York, and Ohio between 1973 and 1975, there were only four reported cases in which the Code's basic risk of loss provision, $\$ 2-509$, was cited. White, Evaluating Article 2 of the Uniform Commercial Code: A Preliminary Empirical Expedition, 75 Mrcr. L. REv. 1262, 1273 (1977).

14 See, e.g., U.C.C. $\$ \$ 2-608$ (permitting revocation of acceptance if a defect substantially impairs the value of the goods, if the goods were accepted either on the reasonable assumption that any defect would be cured or without discovery of the defect, and if revocation occurs within a reasonable time after buyer discovers or should have discovered the defect), 2-712 (permitting damages based on actual cover price if buyer makes a reasonable cover), 2-316(3)(c) (permitting the modification or exclusion of an implied warranty by course of dealing, course of performance, or usage of trade). 
in favor of an attempt to impose rigidly certain standards on an uncertain commercial world. I do suggest, however, that there are sufficient difficulties with specific portions of article 2 to justify a re-examination at this time.

The portion of article 2 that seems to evidence the most pervasive problems is part 7 , which deals with remedies for breach..$^{15}$ It should not be surprising that this would be so, because the remedies provisions of the Code represented substantial departures from past law. The Code differs from its predecessor, the Uniform Sales Act, both in approach, ${ }^{16}$ because its provisions are significantly more specific, $^{17}$ and in substance. ${ }^{18}$ It is not these departures, however, that provide the primary basis for urging revisions of the remedy provisions at this time. Rather, revisions are necessary because the Code's remedy provisions are not sufficiently specific to provide the necessary guidance to courts and litigants, and, in some instances, the Code has not gone far enough in departing from prior law. For example, the Code is unnecessarily vague concerning when to measure market damages after repudiation by a seller. ${ }^{10}$ Courts and commentators have also highlighted serious difficulties in interpreting the scope of the seller's remedy under section 2-708(2). This subsection provides that a seller may recover profit and overhead if the other damage measures are inadequate to put the seller in the same position as the buyer's performance would have. Neither the Code nor the comments give sufficient guidance concerning the situations in which this subsection is applicable or the way in which the subsection's formula is to be applied in various contexts. ${ }^{20}$

15 U.C.C. $\$ \$ 2-701$ to -725 .

16 For one discussion of this difference in approach, see Peters, supra note 8.

17 Compate UNIFORM SALES ACT $\$ \$ 63-65$ and $\$ \$ 66-70$ with U.C.C. $\$ \$ 2-703$ to -710 and $\$ \$ 2-711$ to -716 .

18 For example, U.C.C. $\$ 2-712$ (buyer's cover damages) is entirely new and $\$ 2-706$ (seller's resale damages) represents a substantial expansion of the seller's right to resale damages. Cf. UNIFORM SALES ACT $\$ 60$ (describing seller's right to resale).

19 See, e.g., U.C.C. \$2-713. This section provides that damages are to be based on the market price "when the buyer learned of the breach." When is thatthe date of repudiation, the date performance was due, or the date that the reasonable time for awaiting performance expired? See infra notes $67-82$ and accompanying text.

20 For a decision that ultimately reached the right result in applying $\$ 2-708(2)$ to a lost volume seller, but that did so only after incorrect decisions by the trial court and an intermediate appellate court, see Neri v. Retail Marine Corp., 30 N.Y.2d 393, 285 N.E.2d 311, 334 N.Y.S.2d 165 (1972). See infra notes 102-85 and accompanying text. 
This Article will examine the remedy provisions of article 2 and will consider the problems that have surfaced in the application of those provisions. Various suggestions for revisions of the Code's remedy provisions will be offered. It must be emphasized, however, that I am not suggesting that the remedy provisions of the Code be viewed in isolation. The focus of this Article is upon remedies because these provisions of the Code evidence the most serious difficulties, but other portions of article 2 also should be reviewed carefully with an eye to similar revisions. Piecemeal amendments of isolated provisions in article 2 would be counterproductive, particularly because such amendments would undercut the principle of uniformity. Thus, any suggestions for revision of the remedy provisions of article 2, or for that matter any part of article 2, ultimately should be taken up in the course of an overall review of the article.

\section{An Overview Of Buyers' And Sellers' Remedies}

The basic remedial scheme of article 2 is not very complex and may be sketched briefly. A buyer's monetary remedies for a seller's breach depend initially on whether the buyer retains the goods. The buyer who does not keep the goods, either because the seller never delivers them or because the buyer effectively rejects them ${ }^{21}$ or revokes acceptance, ${ }^{22}$ has two basic remedies. If the buyer in good faith covers by making a reasonable and timely purchase of substitute goods, the buyer may recover damages from the seller measured by the excess of cover price over contract price. ${ }^{23}$ Alternatively, the buyer's damages will be the difference between market price "at the time when the buyer learned of the breach" and contract price. ${ }^{24}$ Under either alternative, the buyer in addition may recover any incidental or consequential damages caused by the seller's breach ${ }^{25}$ together with payments already made to the

21 See U.C.C. \$2-602.

22 See U.C.C. $\$ 2-608$. In the broadest sense, rejection and revocation of acceptance are remedies, and they are important ones for a buyer. The problems encountered under those provisions of the Code, however, will not be discussed in this Article. For an excellent discussion of these provisions of the Code, see Priest, Breach and Remedy for the Tender of Nonconforming Goods Under the Uniform Commercial Code: An Economic Approach, 91 Harv. L. Rev. 960 (1978).

23 U.C.C. \$2-712.

24 U.C.C. $\$ 2-713$. Whether a buyer who covers may still recover market damages under $\$ 2-713$ based on a market price higher than the actual cover price is a matter of some current dispute. See infra notes 90-100 and accompanying text.

25 U.C.C. \$ 2-715. 
seller, ${ }^{28}$ but the buyer must credit the seller with expenses saved because of the breach. ${ }^{27}$ On the other hand, the buyer may retain the goods, either out of choice or because she has accepted them and cannot revoke her acceptance. In this situation, the Code broadly permits the buyer to recover damages for any loss resulting from the seller's breach, ${ }^{28}$ but the damage measure most frequently applied in this situation is the Code's version of the traditional measure of damages for breach of warranty-the difference between the value of the goods as warranted and their actual value at the time and place of acceptance. ${ }^{29}$ In addition, recovery of incidental and consequential damages is allowed. ${ }^{30}$ Finally, in some circumstances the buyer may obtain the goods themselves through an action for specific performance or replevin. ${ }^{31}$

The remedies available to a seller upon a buyer's breach in many respects parallel the remedies provided for buyers. A seller may recover the price, the equivalent of specific performance at law, in three situations: when the buyer has accepted the goods, when conforming goods have been lost or damaged after the risk of their loss has passed to the buyer, and when goods intended for the buyer cannot be resold at a reasonable price. ${ }^{32}$ The Code also provides the seller's equivalent of cover: if the seller makes a good faith and commercially reasonable resale, he may recover the excess of the unpaid contract price over the actual resale price, plus incidental damages but less expenses saved.33 Alternatively, the seller's damages when the buyer does not accept or repudiates is the traditional market value differential-the difference between the unpaid contract price and the market price at the time and place for tender. ${ }^{34}$ The seller has an additional and very significant remedy that has no analogue among buyers' remedies. If the market value differential damages are "inadequate to put the seller in as good a position as performance," the seller may recover the profit he would have made had the buyer fully performed, including

26 U.C.C. $\$ 2-711$.

27 U.C.C. $\$ \S 2-712(2),-713(1)$.

28 U.C.C. $\$ 2-714$ (1).

29 U.C.C. $\$ 2-714(2)$.

${ }^{80} \mathrm{~S} e e$ U.C.C. $\$ \$ 2-714(3),-715$.

31 U.C.C. $\$ 2-716$.

32 U.C.C. $\$ 2-709$.

33 U.C.C. \$2-706.

34 U.C.C. \$2-708(1). 
reasonable overhead, together with costs incurred for performance and incidental damages, but less the payments or proceeds of resale. $^{33}$ Although this profit plus overhead recovery may have been seen by the Code's drafters as a provision that would apply only infrequently, ${ }^{36}$ it is now recognized that, at least in theory, this will be the appropriate measure of damages in a substantial majority of cases involving merchant sellers. ${ }^{37}$ Given this development, it is not surprising that the major problems that have surfaced concerning sellers' remedies have involved this provision. Questions concerning the circumstances in which the section is applicable and the manner in which damages are to be calculated in various situations are particularly significant. ${ }^{38}$

Many of the innovations embodied in article 2's remedial scheme were carefully designed and have worked out well in practice. Cover damages, for example, assure the covering buyer of a good start toward being made whole without risking the vagaries of a judicial determination of market price, and few questions of difficulty have arisen under the cover provision. ${ }^{39}$ The same may be said of the analogous right of a seller to resell and recover the difference between contract price and resale price. ${ }^{40}$ Courts have generally followed the Code's repudiation of the election of remedies doctrine, ${ }^{41}$ much to the relief of plaintiffs who previously were forced unnecessarily to hard choices between rescission and enforcement of the contract. The attempt to restrict the availability of

35 U.C.C. $\$ 2-708(2)$.

36 U.C.C. $\$ 2-704$ comment 1 indicates that the drafters did not foresee that this would be the seller's primary remedy. In the context of their discussion of the seller's ability to finish goods for possible resale after the buyer's breach, the drafters characterized the resale damages of \$2-706 as "the seller's primary remedy" and described the seller's inability to resell the goods as "the special case." The profit plus overhead remedy provision was not even discussed.

${ }^{37}$ See Childres \& Burgess, Seller's Remedies: The Primacy of UCC 2-708(2), 48 N.Y.U. L. REv. 833 (1973).

38 See infra notes 102-85 and accompanying text.

39 Occasionally, there is some dispute over whether the goods subsequently purchased by the buyer were sufficiently similar to the contracted goods to be considered a cover. See, e.g., Valley Die Cast Corp. v. A.C.W. Inc., 25 Mich. App. 321,181 N.W.2d 303 (1970). For a discussion of the situation when a buyer covers by purchasing higher quality goods because those are the only substitutes available at the time, see J. WHITE \& R. SUMMERs, supra note 1, \$6-3, at 221-22.

40 U.C.C. $\$ 2-706$.

41 U.C.C. $\$ 2-703$ comment I. See, e.g., Robinson v. Jonathan Logan Financial, 277 A.2d 115, 116 (D.C. 1971); Durfee v. Rod Baxter Imports, Inc., 262 N.W.2d 349,354 n.6 (Minn. 1977). For a discussion of a remaining election of remedies problem under the Code, see infra notes 90-101 and accompanying text. 
the seller's action for the price ${ }^{42}$ seems to have been successful, ${ }^{43}$ thus implementing the common sense proposition that, normally, resources will be maximized at the least cost if a seller resells rejected goods rather than if the buyer must pay for and then use or resell goods that he no longer wants.44 Even the drafters' modest attempts to encourage courts to grant specific performance of goods contracts more freely ${ }^{45}$ have been somewhat effective. ${ }^{46}$ Other Code remedy provisions, however, have caused considerably more difficulty. It is to those provisions that we now turn.

\section{BUyers' REMEDIES}

\section{A. Should Market Damages Be Eliminated?}

Surprisingly, critical commentary has focused primarily on the traditional market damages remedy of section 2-713, rather than the other buyer remedy provisions. The late Professor Childres launched a direct attack on section 2-713, claiming that the section was superfluous and counterproductive, and urging its repeal.47 Childres argued that it was not realistic in any situation to measure damages, as section 2-713 does, by the difference between market price and contract price. If a market was available, the buyer should be expected to use that market to cover under section 2-712. If there was no market available in which the buyer could have

42 See, e.g., U.C.C. $\$ 2-709$ comment 2.

43 See, e.g., Chicago Roller Skate Mfg. Co. v. Sokol Mfg. Co., 185 Neb. 515, 517-18, 177 N.W.2d 25, 27 (1970); French v. Sotheby \& Co., 470 P.2d 318, 322-23 (Okla. 1970).

44 See Llewellyn, Through Title to Contract and a Bit Beyond, 15 N.Y.U. L.Q: REv. 159, 176-77 (1938). As Llewellyn realized, this assumes that the goods were not already shipped to a distant point. Id.

45 U.C.C. $\$ 2-716$ comment 1, a classic example of gentle persuasion, states: "Without intending to impair in any way the exercise of the court's sound discretion in the matter, this Article seeks to further a more liberal attitude than some courts have shown in connection with the specific performance of contracts of sale." See also Comment, Specific Performance Under Section 2-716 of the Uniform Commercial Code-What "Other Proper Circumstances"?, 33 U. PrrT. L. Rev. 243 (1971).

46 See, e.g., Kaiser Trading Co. v. Associated Metals \& Minerals Corp., 321 F. Supp. 923 (N.D. Cal. 1970); Paloukos v. Intermountain Chevrolet Co., 99 Idaho 740, 588 P.2d 939 (1978). But see Duvall \& Co. v. Malcolm, 233 Ga. 784, 788-89, 214 S.E.2d 356, 359 (1975).

For an argument that specific performance should be more liberally granted, see Schwartz, The Case for Specific Performance, 89 Y YLE L.J..271 (1979). But. see Kronman, Specific Performance, 45 U. CHr. L. Rev. 351 (1978).

47 Childres, Buyer's Remedies: The Danger of Section 2-713, 72 Nw. U.L. Rev. 837 (1978). Professor Childres was working on this article at the time of his death and the article was published posthumously. 
covered, then it would make little sense to measure damages by a hypothetical market price. The buyer who did not cover could not have suffered damages measured by the market price-contract price differential because the buyer never spent money to acquire substitute goods. The buyer's only damages in this situation would be consequential damages, such as lost profits from not having the goods to use in a business operation. Thus, according to Childres, the noncovering buyer should be limited to recovering those consequential damages. ${ }^{48}$

Childres's criticism of the market price damage measure of section $2-713$ also is applicable to the other market damage provisions of article 2. Childres earlier argued that section 2-708(1), which measures a seller's damages by the difference between the unpaid contract price and market price, is artificial and should be ignored or repealed. ${ }^{49}$ A similar criticism probably could be made of the buyer's basic damage measure for breach of warranty found in section 2-714(2), which permits a recovery for breach of warranty measured by the difference between the value of the goods as warranted and their actual value at the time and place of acceptance. If a seller delivers defective goods that the buyer retains, the buyer may suffer various possible losses. The buyer may have the defects repaired, in which case the buyer's actual loss would appear to be the reasonable cost of repair..0 If the goods are not repaired, or if repairs do not fully restore the goods to their warranted condition,

48 Id. 842-44. A minor qualification to Childres's point is that the noncovering buyer should recover for incidental losses that she might also suffer, such as the cost of fruitless attempts to cover or the cost of storing rejected goods. See U.C.C. $\$ \$ 2-713(1),-715(1)$.

49 Childres \& Burgess, supra note 37 , at $880-85$.

. 50 Many courts and commentators have seen the cost of repair as a convenient measure of damages under $\$ 2-714(2)$. See J. WhrTE \& R. SuMmers, supra note 1 , $\$ 10-2$, at 377-78; Special Project, Article Two Warranties in Commercial Transactions; 64 CoRNELx L. Rev. 30,107-12 and cases cited therein. The language of this subsection, however, referring to differences in value as the measure of damages, by no means compels such a result. In fact, courts awarding repair damages have frequently relied upon other provisions of the Code. Some courts have found this interpretation implicit in $\$ 2-714(1)$, allowing for damages determined in "any manner which is reasonable." See, e.g., Fargo Mach. \& Tool Co. v. Kearney \& Trecker Corp., 428 F. Supp. 364, 383 (E.D. Mich. 1977). In other cases, courts have awarded the cost of repair for a breach of warranty under the "special circumstances" clause of \$2-714(2). See, e.g., General Supply \& Equip. Co. v. Phillips, 490 S.W.2d 913, 919 (Tex. Civ. App. 1972). Following still another approach, the cost of repairs has been held to be consequential damages under $\$ 2-715$. See, e.g., Southern Concrete Prods. Co. v. Martin, 126 Ga. App. 534, 536, 191 S.E.2d 314, 316 (1972). At least one court has not awarded the cost of repairs to the plaintiff in a breach of warranty claim, stating that $\$ 2-714(2)$ specifies that the damage measure is the difference in value. See Chaq Oil Co. v. Gardner Mach. Corp., 500 S.W.2d 877, 878 (Tex. Civ. App. 1973). 
the buyer may suffer various consequential losses by having to use lesser quality goods, and the buyer should recover for those losses, as the Code provides. ${ }^{51}$ Finally, the buyer might resell the defective goods and, because of the defects, receive a lower price than she would have obtained had they been conforming. ${ }^{52}$ It seems fair to say that in each case the difference in value formula of section 2-714(2) is not the best measure of any of these potential losses.

One can concede that the Code's market damage formulae normally are not realistic measures of most actual losses suffered, but still not agree with Childres that those damage provisions should be repealed. In fact, there are substantial arguments for retaining the traditional market damage measures. First, there are a few situations in which a market damage formula probably is the best measure of the actual loss suffered. Consider the buyer who does cover but is held not to have done so in a reasonable manner, thus losing the right to have damages measured by the difference between contract price and the actual cover price under section 2-712. This buyer has suffered an actual loss and should be deprived of recovery only to the extent that her unreasonable actions contributed to the loss. The best solution here is to permit this buyer, as the Code presently does, ${ }^{53}$ to recover market damages under section 2-713, because the market price represents the best evidence of the cost of a reasonable cover. ${ }^{54}$ The market price measure is also likely to be a decent measure of actual loss in the case of goods, such as art or coins, that appreciate in value and are held in part as investments. The market price-contract price differential is the best estimate of

51 See U.C.C. $\$ \S 2-714(3),-715$ :

52 Lost resale profits, if foreseeable and proven with sufficient certainty, would be recoverable as consequential damages under $\$ 2-715(2)$. Because goods generally depreciate in value, however, the difference in value measure of $\$ 2-714(2)$ would not be a good approximation of any loss on resale that the buyer might eventually suffer if she holds the goods for a time before reselling. Section 2-714(2)'s measure of the difference in value at the time of acceptance would probably be the highest likely difference in value. If, for example, the buyer plans to use the goods for three years and then resell them, the difference in value on actual resale is likely to be considerably less than the difference at the time of acceptance.

5s U.C.C. \$2-712(3) states: "Failure of the buyer to effect cover within this section does not bar him from any other remedy.".

54 For cases holding that a buyer who covers improperly may still recover market damages under \$2-713, see, e.g., Oloffson v. Coomer, 11 Ill. App. 3d.918, 296 N.E.2d 871 (1973) (buyer's cover was unreasonably delayed). Similarly, a seller who resells but does not comply with \$ 2-706 still may recover market damages under $\$ 2-708(1)$. See U.C.C. $\$ 2-706$ comment 2; Lee Oldsmobile, Inc. v. Kaiden, 32 Md. App. 556, 363 A.2d 270 (1976). 
the buyer's advantageous bargain at the time of breach. The buyer then is free to use the damage award either to purchase similar goods or to make other investments. In either case, the eventual gain from the new purchase or investment will serve as a rough substitute for the future appreciation of the goods. ${ }^{55}$

The second reason for retaining a market damage measure of recovery is more important. Even if one agrees with Childres that normally the only losses that the noncovering buyer will actually suffer are consequential and incidental damages, such as lost profits or the expenses of a fruitless attempt to cover, obtaining recovery. for such losses is not an easy matter. The buyer must establish that the seller could foresee the consequential losses at the time of contracting. ${ }^{56}$ The buyer also must mitigate damages and cannot recover for losses that could have been avoided "by cover or otherwise." 57 And, perhaps the most serious limitation of all, the buyer must show that the loss was caused by the seller's breach and must establish the amount of loss with a reasonable degree of certainty. ${ }^{58}$ All of these limitations, plus the traditional American rule against recovery of attorneys' fees, ${ }^{59}$ make it extremely unlikely that the buyer will obtain damages that will, in fact, satisfy the Code's traditional contract remedy objective of placing her in the same economic position that she would have been in had the contract been performed. ${ }^{\text {b0 }}$ As Professor Farnsworth has observed, "our system of legal remedies for breach of contract . . . has shown a marked solicitude for men who do not keep their promises." ${ }^{1}$

55 Of course, the income from investing the damage award has no necessary relationship to the appreciation of any particular item. But, considering the problems with predicting the rate of appreciation and the amount of time the buyer would have kept the item, it is not unreasonable to measure damages by the market price based on the assumption that the buyer might have sold the item immediately to realize on her profitable contract with the seller.

56 U.C.C. $\$ 2-715(2)(\mathrm{a})$.

$57 \mathrm{Id}$.

58 The Code attempts to relax the certainty requirements by rejecting any requirement that damages be calculable with mathematical accuracy. See U.C.C. $\$ \$ 1-106$ comment 1, 2-715 comment 4. In other contexts, some courts also have held that it is appropriate to insist upon a less stringent standard of certainty once the fact of loss is established and the only question is the quantum of loss. See, e.g., A to Z Rental, Inc. v. Wilson, 413 F.2d 899, 908 (10th Cir. 1969); Wilson v. Farmers Chem. Ass'n, 60 Tenn. App. 102, 111, 444 S.W.2d 185, 189 (1969).

59 For a discussion of the American rule, see D. DoBbs, HaNDBOOK on THE LAW of REMEDIES $\$ 3.8$, at 194-204 (1973).

${ }^{60}$ See U.C.C. $\$ 1-106(1)$.

61 Farnsworth, Legal Remedies for Breach of Contract, 70 Colum. L. REv. 1145,1216 (1970). 
In this context, the market damage differential formula of section 2-713 can be justified as a reasonable means of assuring some minimal recovery for a buyer when the seller breaches in a rising market. ${ }^{62}$ The buyer who neither covers nor obtains specific performance is still likely to suffer some loss in the way of consequential or incidental damages, but it often will be difficult and costly from a litigation standpoint to meet the prerequisites for recovering those damages. The market damage measure of section $2-713$ provides an alternative recovery that is likely to be less difficult and less costly to obtain than incidental and consequential damages, and one that is unlikely to overcompensate the plaintiff. In a sense, then, it is not unreasonable to view section 2-713 as a type of statutory liquidated damages provision ${ }^{63}$ intended to assure the buyer of at least a minimal recovery that is relatively easy to obtain. ${ }^{64}$

If this market damage differential is justified as essentially a minimum damages provision, is it reasonable to award those minimum damages only when the seller breaches in a rising market, as does section 2-713? ${ }^{65}$ Here it must be remembered that the minimum damages justification for section $2-713$ is based on the assumption that the buyer is very likely to have suffered some actual damages and is unlikely to be overcompensated by a market damage differential award. This assumption is considerably less sound in a falling market in which the buyer could have covered at less than the contract price. When a falling market is involved, there is considerable risk that whatever incidental or consequential damages the buyer might have suffered would be offset by savings in the cover price. Thus, a minimum damage provision that was appli-

62 While courts probably should be more lenient than they have been in the past with respect to the foreseeability and certainty requirements for recovery of consequential loss, it is doubtful that any further revision of the Code would be helpful in this regard. One author, however, has recently suggested that a buyer should be entitled to a minimum recovery equal to any gain that the seller received because of the breach. Schiro, Prospecting for Lost Profits in the Uniform Commercial Code: The Buyer's Dilemmas, 52 S. CAI. L. Rev. 1727, 1749-50 (1979). This proposal may go too far and might frequently result in overcompensating the buyer.

63 This view of $\$ 2-713$ has been suggested previously. See J. WHITE \& $R$. SunOMERs, supra note $1, \S 6-4$, at 225 .

64 A similar justification exists for $\$ 2-714(2)$, which gives a buyer who retains goods despite a breach of warranty damages measured by the difference between the value of the goods as warranted and their value as accepted. Even if the buyer cannot establish with sufficient certainty the consequential losses caused by. a breach of warranty, such as a reduction in profits earned through use of the goods, the difference in value formula of $\$ 2-714(2)$ might be viewed as a general approximation of the capitalized value of possible lost future profits.

65 If the market price is less than contract price, market damages under $\$ 2-713$ obviously will be zero. 
cable in a falling market might often overcompensate the buyer. In light of this risk, the Code is correct in not providing a minimum damage provision for the benefit of a buyer in a falling market. ${ }^{68}$

\section{B. Market Damages After Anticipatory Repudiation}

While there are sound reasons to retain the traditional market price damage measure, the particular version embodied in section 2-713 has a number of serious defects. The most difficult interpretive problem under that section is when to measure market damages when a seller repudiates before performance is due. Section 2-713 provides that the market price is to be measured "at the time when the buyer learned of the breach," leaving unanswered the crucial question of when the buyer is deemed to have learned of the breach. Courts and commentators have suggested three different times to measure the market price. Some courts, without much discussion, have adopted the date the buyer learned of the repudiation as the proper point for measuring market damages. ${ }^{67}$ Quite a few courts have said that the buyer can await performance for a commercially reasonable time after repudiation, and that damages should be measured at the end of this period. These courts have differed, however, on when that reasonable time ends. ${ }^{68}$ Surprisingly, no court has unequivocally adopted the date of per-

66 It should also be noted that a breach by a seller is much less likely to occur in this situation. In a falling market, it is normally in the seller's economic interest to perform, if at all possible.

67 See, e.g., Baker v. Ratzlaff, 1 Kan. App. 2d 285, 564 P.2d 153 (1977); Tennell v. Esteve Cotton Co., 546 S.W.2d 346 (Tex. Civ. App. 1976); Bliss Produce Co. v. A.E. Albert \& Sons, Inc., 35 Agric. Dec. 742 (1976); cf. Sawyer Farmers Coop. Ass'n. v. Linke, 231 N.W.2d 791 (N.D. 1975) (liquidated damages provision, specifying market price to be measured when contract closed, interpreted as date buyer learns of repudiation). Section 2-723 of the Code contains a special rule clearly providing that market damages are to be measured at the date that the buyer learns of repudiation in one situation-when the case comes to trial before the date of performance. Because trials are rarely held that promptly, this special rule is applied infrequently.

68 See, e.g., First Nat'l Bank v. Jefferson Mortgage Co., 576 F.2d 479 (3d Cir. 1978) (reasonable time ends at date of repudiation); Cargill, Inc. v. Stafford, 553 F.2d 1222 (10th Cir. 1977) (reasonable time ends on the date buyer cancelled the contract unless it was reasonable for buyer to wait longer to attempt a cover); Oloffson v. Coomer, 11 Ill. App. 3d 918, 296 N.E.2d 871 (1973) (reasonable time ends at date of repudiation); Carson v. Mulnix, 263 N.W.2d 701 (Iowa 1978) (reasonable time ends at date of performance); Leibson, Anticipatory Repudiation and Buyer's Damages-A Look Into How the UCC Has Changed the Common Law, 7 U.C.C. L.J. 272 (1975); Peters, supra note 8, at 266-67; cf. U.C.C. $\$ 2-610$ (giving an aggrieved party, after repudiation, the choice of resorting to any remedy for breach or awaiting performance "for a commercially reasonable time"). 
formance as the time for measuring damages after a seller's repudiation, ${ }^{69}$ although some commentators have urged this approach. ${ }^{70}$ While the lack of clarity in section 2-713 makes it understandable that courts might reach such different results, it is distressing that some of the opinions on this issue are flawed by unpersuasive and inconsistent analysis. ${ }^{71}$

${ }^{69}$ Carson v. Mulnix, 263 N.W.2d 701 (Iowa 1978), comes close to adopting the date of performance standard. While the parties disputed when performance was due, the court concluded that the contract required the seller to perform within a reasonable time, but not later than December 31, and measured market damages as of the end of December. The court assumed the repudiation occurred in late August when the seller failed to respond to the buyer's demand for overdue deliveries. The buyer apparently did nothing after that time. The court merely stated in conclusory terms that it was not unreasonable for the buyer to await performance until the end of December, but the court did not discuss the circumstances at all or indicate what justified such a long wait. Id. 706-07.

Although the court in Carson assumed there had been a repudiation, its decision may have been influenced by some doubt on that point. There was no overt statement of intent not to perform by the seller, so the only possible repudiation would be through the seller's silence in face of the buyer's demand for performance. Failure to give adequate assurances after a justified demand for assurances is considered a repudiation, see U.C.C. $\$ 2-609$, but there might be some doubt whether the buyer's demand for performance would amount to a demand for assurances under $\$ 2-609$, particularly in light of the dispute concerning when performance was due. If there was no repudiation, there would have been no breach until the time for performance expired, and then late December undoubtedly would have been the proper time to measure damages under $\$ 2-713$.

70 See J. WhrTE \& R. SUMDMERs, supra note 1 , $\$ 6-7$, at 242-47; Anderson, Learning of Breaches Under Section 2-713 of the Code, 40 TEx. B.J. 317 (1977). Measuring a buyer's market damages at the date of performance would be consistent with the Code's treatment of a seller's market damages, for in $\$ 2-708$ (I) the Code unequivocally states that a seller's market damages are to be measured "at the time and place for tender." White and Summers argue that the only reason for the "learned of the breach" language in $\$ 2-713$ was to permit measuring a buyer's damages at a time after the date for performance if the buyer did not learn of the breach until after that date, such as if the buyer did not discover that goods were defective until some time after delivery: J. WHrTE \& R. SUMmens, supra note $1, \$ \$ 6-7$, at $244-45$.

The time of performance is the time at which market damages would have been measured under prior law. See, e.g., Reliance Cooperage Corp. v. Treat, 195 F.2d 977 (8th Cir. I952).

71 Cargill, Inc. v. Stafford, 553 F.2d 1222 (10th .Cir. 1977), is a prime example of the confusion and inconsistencies in judicial measurements of a buyer's damages after anticipatory repudiation. In this case, the contract called for delivery of wheat on September 30, but the seller repudiated on August 24 and the buyer cancelled the contract on September 6. The court initially, and apparently unequivocally, agreed with the White and Summers position, see supra note 70 and accompanying text, that damages should be measured at the time for performance. 553 F.2d at 1226. But then, without recognizing any inconsistency with its previous statements, the court concluded that damages normally should be measured by the market price at the end of the commercially reasonable time that the buyer could await performance. The court further concluded that the reasonable time ended on September 6, when the buyer cancelled the contract, and that damages should be measured as of September 6 unless, on further hearing, the buyer established a valid reason for failing to cover immediately. If the buyer showed such a reason, damages were to be based upon the market price at the September 30 delivery 
The inability of the courts to reach a reasoned consensus concerning the application of section 2-713 in the anticipatory repudiation situation indicates the urgent need for revision of that section. Absent consensus on this important issue, we are deprived of many of the benefits that the Code was designed to produce. Parties are unable to assess the probable outcomes in the event of breach and possible litigation, judges must resolve unnecessarily difficult issues each time they decide a case, and the results are not always rational and fair. Moreover, even if one views section $2-713$ as a residual minimum damages provision having only a tenuous relation to the actual damages suffered by a buyer, ${ }^{72}$ the point at which damages are measured is significant. It is important to adopt the measure of damages that is most consistent with the other remedial provisions of the Code to ensure that the underlying remedial policies are effectively implemented.

While section 2-713 should be revised, it should be emphasized that it is also possible to interpret the existing provision in a reasonable and consistent manner. In developing either a sensible interpretation of the existing provision or a recommendation for revision of that provision, two of the underlying remedial policies of the Code are paramount. First, when either party repudiates a contract before performance is due, the aggrieved party is entitled to await performance for a reasonable time after repudiation. ${ }^{73}$ Second, although the buyer is not required to cover, ${ }^{74}$ she is strongly encouraged to do so, and to do so relatively quickly. ${ }^{75}$ Both of these policies point toward measuring the buyer's market damages after repudiation at the end of the commercially reasonable time for awaiting performance.

date. Id. 1227. The court, however, offered no guidance concerning what circumstances might justify delaying cover. In the end, then, the court managed to ignore or substantially limit the date of performance measure that it had initially pronounced. Instead, it adopted a measure based primarily upon the market price at the end of the reasonable time that the buyer is entitled to await performance, unless the buyer could show a valid reason why she could not cover at that time.

72 See supra notes 62-64 and accompanying text.

73 See U.C.C. $\$ 2-610$.

74 U.C.C. $\$ 2-712(3)$ provides: "Failure of the buyer to effect cover within this section does not bar him from any other remedy."

${ }^{75}$ Failure to cover may deprive the buyer of recovery for consequential losses that could have been avoided by cover. See U.C.C. $\$ 2-715(2)$ ("consequential damages .... include ... any loss ... which could not reasonably be prevented by cover or otherwise"); U.C.C. $\$ 2-712$ comment 3. A proper cover also relieves the buyer of the vagaries of a market price determination. Impetus toward a speedy cover is provided by $\$ 2-712$ itself, which provides that cover must be made "without unreasonable delay." 
Measuring market damages at the date that performance is due is inconsistent with the principle that the buyer may await performance only for a commercially reasonable time after repudiation. If the seller has not retracted his repudiation by the end of that reasonable time, the buyer should cancel the contract and cover. Failure to cover within a reasonable time after the repudiation will deprive the buyer of the right to have damages measured by the difference between the price of substitute goods and the contract price under section 2-712. Instead, the buyer will be limited to market damages under section 2-713.78 If those market damages are measured at the time of performance, however, the incentive for the buyer to cover promptly is significantly reduced. With a date-ofperformance measure, the buyer could wait until the date of performance to cover. Then, even if that cover was too delayed to meet the reasonable time requirements of section 2-712, the buyer could still essentially recoup full cover damages by having the market price under section 2-713 measured as of the date of performance. Particularly in an inflationary economy, when it is much more likely that the price will go up than that it will go down, the date-ofperformance measure presents too great a risk that the seller's damage liability will be increased without there being any justification for that increase in the legitimate needs of the buyer. ${ }^{77}$

${ }^{76}$ See, e.g., Oloffson v. Coomer, 11 Ill. App. 3d 918, 296 N.E.2d 871 (1973).

i7 There also is an economic justification for rejecting the date-of-performance measure. From the standpoint of economic efficiency, contract law should not discourage "efficient" breaches of contract. If the seller has a more valuable use for the resources that were to be devoted to performing the contract, and if that alternative use produces a net increase in value even after paying the losses suffered by the other party to the contract, then breach of the contract is efficient and should be permitted. The obligation to pay the actual losses suffered by the other party is the only sanction needed. See R. Posner, Economic Analysis of Law $\$ 4.9$ (2d ed. 1977); REstatement (SECOND) of Contracts introductory note to chapter 16 (student ed. 1981). If market damages are measured at the date of performance rather than at a time closer to the date of repudiation, it is more difficult for the seller to predict what its damage liability might be at the time of repudiation. Under this later measure of damages, it is more difficult for the seller to determine if the repudiation will be economically efficient. See Jackson, "Anticipatory Repudiation" and the Temporal Element of Contract Law: An Economic Inquiry into Contract Damages in Cases of Prospective Nonperformance, 31 STaN. L. Rev. 69, 93-94 (1978). The new Restatement (Second) of Contracts provides some support for the proposition that after an anticipatory repudiation the buyer should not always be entitled to have market damages measured at the date of performance. In discussing the avoidable consequences rule, the comment states:

The injured party is expected to arrange a substitute transaction within a reasonable time after he learns of the breach. He is expected to do this even if the breach takes the form of an anticipatory repudiation, since... he is then protected against the possibility of a change in the market before the time for performance.

Restatement (SECOND) of Contracts $\$ 350$ comment $f$ (student ed. 1981). 
Measuring market damages at the date of repudiation is also inconsistent with the Code's dual policies of encouraging cover and permitting an aggrieved party to await performance for a reasonable time after repudiation. ${ }^{78}$ The buyer who reasonably awaits performance after repudiation and then either cannot cover or makes a cover that for some reason does not qualify under section 2-712 ${ }^{79}$ should not have damages based on market price as of the date of repudiation. Measuring the market at this earlier date when it was probably lower will unjustifiably penalize the buyer who has properly chosen to insist on performance.

The language of the Code and its explanatory comments also support the view that the buyer's market damages in the case of an anticipatory repudiation should be measured as of the end of the commercially reasonable time for awaiting performance. First, this result comports with the entreaty of the comment to section 2-713, which states that market damages are to be measured in "the market in which the buyer would have obtained cover." 80 Moreover, the

78 As noted previously, $\$ 2-723$ does provide that market damages shall be measured as of the time of repudiation when the case comes to trial before the date of performance. See supra note 67. This special rule aids the argument that "time he learned of the breach" in $\$ 2-713$ does not mean date of repudiation. The Code drafters knew how to say "date of repudiation" if that is what they meant. Interpreting $\$ 2-713$ to mean date of repudiation would make $\$ 2-723$ useless, at least as applied to buyers' remedies. See Cargill, Inc. v. Stafford, 553 F.2d 1222, 1226 (10th Cir. 1977); J. WhITE \& R. Summers, supra note 1, $\$ 6-7$, at 245-46.

79 The buyer's purchase may not qualify, for example, if the goods bought are so different in character or quality that they are not deemed substitute goods. See, e.g., Valley Die Cast Corp. v. A.C.W. Inc., 25 Mich. App. 321, 181 N.W.2d 303 (1970).

80 U.C.C. $\$ 2-713$ comment 1 . If the objective is to measure market damages in the market in which the buyer is most likely to cover, it could be argued that damages should not be measured at the end of the commercially reasonable time for awaiting performance but rather at the end of some further reasonable time for arranging cover. The court in Cargill, Inc. v. Stafford, 553 F.2d 1222 (10th Cir. 1977), took an approach somewhat similar to this, holding that if there was a valid reason for not covering the market damages should be measured as of the date of performance, but if there was no such reason, market damages would be measured as of the end of the reasonable time for awaiting performance. Id. 1227; see supra note 71 and accompanying text.

For two reasons, it is doubtful that it is worth fine tuning the market damage measure so that damages would be measured at the time the buyer should reasonably have covered. First, in the anticipatory repudiation situation, that measure would require the court to decide two potentially difficult and unclear issues: not only when the reasonable time for awaiting performance ended, but also how long the further reasonable time for effecting cover lasted. Absent strong policy reasons that do not appear to exist in this situation, it seems sufficient to focus only on the first and most important question, that of when the reasonable time for awaiting performance expired. Moreover, in the case of a repudiation, it is likely that the end of the time for awaiting performance and the end of any further reasonable time to effect cover might be quite close. One might reasonably expect that the buyer, while awaiting performance and attempting to convince the seller to retract his repudia- 
"end of a reasonable time" measurement date is an appropriate interpretation of the language of section 2-713 because a buyer does not actually "learn of the breach" until the reasonable time for awaiting performance has expired under section 2-610. It is not until that time has passed without a retraction of the repudiation that the buyer is relatively certain that the seller will not perform. ${ }^{81}$ In short, then, the language and the remedial policies of the Code suggest that after a seller repudiates a contract, a buyer's market damages should be measured at the end of the commercially reasonable time for awaiting performance, or at any earlier time that the buyer actually cancels the contract. ${ }^{82}$

If a court adopts this sensible interpretation of section 2-713, there remains the important question of the length of the commercially reasonable time to await performance. Some courts have followed an unduly simplistic approach on this issue, ruling that when the repudiation is unequivocal and there is a readily available market in which cover could be had, the aggrieved buyer has no right to await performance. Under these decisions, market damages effectively are measured at the date of repudiation..$^{83}$ This approach ignores the principal purpose for letting an aggrieved party await performance: to permit her some time to convince the repudiator to

tion, also would be canvassing the cover market so that he would be ready to make a cover purchase soon after he decided to cancel the contract or the reasonable time for awaiting performance expired.

Second, a suggestion to measure the market price at the end of some reasonable time for affecting cover would have implications for the case of a present breach as well as for the anticipatory repudiation situation. It would be hard to argue that damages should be measured at the end of some further reasonable time for effecting cover in the anticipatory repudiation situation but not in the case of present breach. Changing the time for measuring damages in the case of a present breach, however, would create an issue about which litigation and dispute would be possible in any action for market damages, rather than merely in the anticipatory repudiation context. This seems unnecessary because, in the case of a present breach, there is no need to make the damage measure comport with $\$ 2-610$ 's policy, applicable only in anticipatory repudiation situations, limiting the right to await performance to a commercially reasonable time.

81 The courts that have adopted the "end of a reasonable time" interpretation of $\$ 2-713$ have reached the preferable result. See, e.g., First Nat'l Bank v. Jefferson Mortgage Co., 576 F.2d 479 (3d Cir. 1978); Cargill, Inc. v. Stafford, 553 F.2d 1222 (10th Cir. 1977); Oloffson v. Coomer, 11 Ill. App. 3d 918, 296 N.E.2d 871 (1973).

82 Cancellation establishes the buyer's own decision not to wait for performance and indicates the time at which the buyer should be seeking cover. See U.C.C. $\$ 2-611(1)$.

83 For example, the court in Oloffson v. Coomer, 11 Ill. App. 3d 918, 296 N.E.2d 871 (1973), held that the reasonable time for awaiting performance was zero and that market damages were to be measured at the date of repudiation. See also First Nat'l Bank v. Jefferson Mortgage Co., 576 F.2d 479 (3d Cir. 1978). 
retract his repudiation and go on with performance. ${ }^{84}$ Even if the repudiation is unequivocal (which is necessary for a repudiation anyway) ${ }^{85}$ and cover is readily available, it will be in the best interests of both the aggrieved party and the judicial system to have the contract performed. Performance will avoid litigation, saving the aggrieved party the unrecoverable costs of obtaining satisfaction from the repudiator. ${ }^{86}$ Thus, the remedial scheme should encourage reasonable attempts to obtain performance by postponing the measurement of market damages during the pendency of reasonable good faith attempts to obtain a retraction. ${ }^{87}$

For a broad yardstick as to the appropriate length of time to await performance, an analogy can be drawn between the aggrieved party's position following an anticipatory repudiation and the posi-

84 U.C.C. $\$ 2-611$ (1) makes it clear that in many circumstances the repudiator can retract his repudiation. The section provides that "[u]ntil the repudiating party's next performance is due he can retract his repudiation unless the aggrieved party has since the repudiation cancelled or materially changed his position or otherwise indicated that he considers the repudiation final." Of course, the aggrieved party is not compelled to seek retraction. If the repudiation is substantial and unequivocal, $\$ 2-610$ permits immediate cancellation and resort to all remedies for breach.

85 Although the Code does not expressly define repudiation, the comment indicates that the traditional insistence on an unequivocal repudiation is continued: "[A]nticipatory repudiation centers upon an overt communication of intention or an action which renders performance impossible or demonstrates a clear determination not to continue with performance." U.C.C. $\$ 2-610$ comment 1 .

86 At worst, allowing the buyer to wait may increase the costs of the transaction. Assuming that the repudiation occurred because market prices were steadily rising, the longer the buyer could await performance, the more she might have to pay for substitute goods. Additionally, waiting may increase the buyer's consequential losses. Of course, the possibility of substantial market price increases or consequential losses in any particular situation is relevant in determining the appropriate length of the reasonable time for awaiting preformance. But even in the face of such risks, it would seem that the buyer normally should have at least a few days to attempt to secure a retraction from the repudiating seller.

87 But see Jackson, supra note 77, at 98-101, 111. Professor Jackson argues that $\$ 2-610$ 's right to await performance should be read narrowly, and that the time for covering and measuring market damages should extend beyond the date of repudiation only in limited circumstances. He recognizes that a good faith belief that the repudiator will change his mind is one of those circumstances, but seems to suggest that such a good faith belief might exist only if there was a continuing business relationship that the aggrieved party might think would be worth preserving.

Jackson's position ignores the fact that, even absent a continuing business relationship, an aggrieved party will have incentives to avoid litigation, and thus will have valid reasons to attempt to convince the repudiator to retract. The Restatement (Second) of Contracts recognizes this important interest. While stating that even in the anticipatory situation the aggrieved party should enter into a substitute transaction within a reasonable time after repudiation, the drafters explicitly note that appropriate efforts by the aggrieved party to urge retraction will be considered in determining the length of the reasonable time. REstatement (SEcond) of Contracts $\$ 350$ comment $f$ (student ed. 1981). 
tion of a party who has grave doubts as to the other party's performance. In the latter situation, section 2-609 provides that if one party has reasonable grounds for insecurity about the other's future performance, the insecure party may make a written demand for assurances. Failure to give adequate assurances within a reasonable time not exceeding thirty days amounts to a repudiation. By analogy, after a seller's repudiation, the insecure buyer should be able to demand continued performance and normally wait thirty days before the buyer's reasonable time for awaiting performance would expire.

While thirty days should normally be the reasonable period for awaiting performance, various factors could justify shortening the thirty day waiting period in any individual case, just as the time for awaiting assurances under section 2-609 may often be less than thirty days. In the anticipatory repudiation situation, these factors would include an unequivocal reiteration of the repudiation, a predictably rising cover market, or the necessity for earlier cover to avoid consequential loss to the buyer. Extending the waiting period might be justified only in rare circumstances, such as if the seller appeared to be actively considering retraction. ${ }^{88}$

In summary, then, important considerations of policy argue for measuring a buyer's market damages after repudiation at the end of the commercially reasonable time for awaiting performance, or at any earlier time that the buyer actually cancels the contract. While it is possible to reach this result under the current Code, the difficulties of interpretation are substantial. Such lack of clarity is generally undesirable, and there is no particular reason in this instance to give the courts flexibility by leaving the ambiguity unresolved. Thus, the Code should be revised to provide clearly that a buyer's market damages after an anticipatory repudiation are to be measured

88 One additional matter should be raised briefly in relation to the measurement of a buyer's market damages after an anticipatory repudiation. Assuming that damages are measured at the end of the commercially reasonable time for awaiting performance, what market price should be used-the spot price for immediate delivery or the future market price for delivery at the date of performance? A number of the cases appear to have used the spot market price. See, e.g., Cargill, Inc. v. Stafford, 553 F.2d 1222 (10th Cir. 1977); Baker v. Ratzlaff, 1 Kan. App. 2d 285, 564 P.2d 153 (1977). But see Oloffson v. Coomer, 11 Ill. App. 3d 918, 296 N.E.2d 871 (1973) (market price for future delivery). If there is a difference between the prices, however, the price for future delivery should be used. The future delivery price is the closest substitute for the seller's agreed performance, and using the spot price may violate the expectancy principle of contract damages by giving the buyer the value of goods in hand before she was entitled to receive them under the contract. Moreover, the spot price will almost never be less than the future price plus the cost of storage and other incidental expenses, but it may be higher. See Jackson, supra note 77, at 94-96. 
as of the end of the commercially reasonable time for awaiting performance or at the time that the buyer actually cancels the contract, whichever is earlier. ${ }^{89}$ Moreover, additional guidance should be provided, possibly in a comment, concerning the length of the reasonable time for awaiting performance so that courts do not easily conclude that the time ends on the date of the initial repudiation.

\section{Election of Remedies}

The problem of election of remedies under the Code's damages provisions also calls for some attention. With respect to buyers' remedies, the question is whether a buyer who covers may nevertheless decline to seek damages under section 2-712 and instead recover market damages under section 2-713 based upon a market price higher than the actual cover price. A similar issue arising under the sellers' remedies provisions will be considered at the same time: may a seller who resells still recover market damages under section 2708 (1) based upon a market price lower than the actual resale price?

It is possible to read the Code as providing that the buyer who covers is bound by the actual cover price but that the seller who resells is not similarly bound. A comment to section 2-713 states broadly that market damages are available only to the extent that the buyer has not covered, ${ }^{90}$ but there is no similar comment to the sellers' market damage provision. ${ }^{91}$ Perceiving no reason that sellers and buyers should be treated differently, some have argued that both sellers and buyers should be free to seek market damages regardless of any actual resale or cover. ${ }^{92}$ While conforming to prior law, ${ }^{93}$ this interpretation runs counter to the general objective of contract remedies and of the Code-to put the aggrieved party in as good a position, but no better, than he would have been in had the contract been performed. ${ }^{94}$ The aggrieved party is fully compensated

89 For discussion of a similar proposal concerning sellers' market damages under $\$ 2-708(1)$, see infra notes 203-11 and accompanying text.

90 "The present section provides a remedy which is completely alternative to cover under the preceding section and applies only when and to the extent that the buyer has not covered." U.C.C. $\$ 2-713$ comment 5 .

91 See U.C.C. $\$ 2-708$ \& comments.

92 See Peters, supra note 8, at 259-61; Vernon, Expectancy Damages for Breach of Contract: A Primer and Critique, 1976 WASH. U.L.Q. 179, 190-93.

93 See UNIFORM SALES ACr $\$ \$ 64,67$. Under the Uniform Sales Act, there was no provision for measuring damages based on the cost of cover, so covering did not preclude the buyer from recovering market damages.

94 U.C.C. $\$ 1-106(1)$ provides:

The remedies provided by this Act shall be liberally administered to the end that the aggrieved party may be put in as good a position as if the 
by a recovery based upon the actual resale or cover price, and there is no justification for increasing the breacher's damage liability merely because a hypothetical market price is different from the actual resale or cover price. ${ }^{95}$

Although the Code is open to different interpretations, it is both possible and preferable to interpret the existing provisions as forcing both a buyer and a seller to an election between cover or resale damages and market damages. 'The index sections for buyers' and sellers' remedies provide that a buyer may " 'cover' and have damages under [section 2-712]," 96 and that a seller may "resell and recover damages as hereafter provided (Section 2-706)." 97 The use of the conjunction "and" mandates the buyer who covers and the seller who resells to measure damages under sections 2-712 or 2-706, respectively. Both of these index sections, then, can be viewed as consistent with the proposition that a buyer who covers and a seller who resells are bound by the actual cover or resale prices.

other party had fully performed but neither consequential or special nor penal damages may be had except as specifically provided in this Act or by other rule of law.

See generally Farnsworth, supra note 61 , at 1147-49 (examining different damage measures for breach).

05 One author has argued that a buyer who covers promptly should be limited to the actual cover price, but that if cover is delayed so as not to meet the requirements of $\$ 2-712$, then the buyer should be entitled to recover based on a market price that exceeds the actual cover price. The argument is that because the buyer's delayed cover is not entitled to the protection of $\$ 2-712$, the buyer assumes the risk that the market price will be less than the cover price and should get the benefit of any market price above the cover price. Jackson, supra note 77, at 113-16. Because it is the buyer who chooses to delay cover, however, such a delay does not provide a justification for imposing an additional damage liability on the seller when the buyer will be fully compensated by a recovery based on the actual cover price. Considering the Code policy of encouraging cover, there seems no reason to give a windfall to a buyer who fails to make a proper cover.

Not many cases have directly considered the question of the election between market damages and cover or resale. In Flood v. M.P. Clark, Inc., 335 F. Supp. 970 (E.D. Pa. 1971), the court explicitly held that a buyer who covers may recover no more than the difference between cover price and contract price. Id. 97I. Similarly, another case held that a seller who resells without satisfying the requirements of $\$ 2-706$ cannot receive more under $\$ 2-708(1)$ than the seller's actual loss-the difference between the contract price and the actual resale price. Coast Trading Co. v. Cudahy Co., 592 F.2d 1074, 1081-83 (9th Cir. 1977). Professors White and Summers also endorse this view. They argue that the aggrieved party who covers or resells normally should not be permitted to recover more under the market damage provisions of the Code than he would have if damages were based on the actual cover price or resale price. J. Whare \& R. Summers, supra note 1, $\$ \$ 6-4,7-7$, at $233-34,271-73$. On the other hand, in Bache \& Co. v. International Controls Corp., 339 F. Supp. 341, 352-53 (S.D.N.Y.), affd per curiam, 469 F.2d 696 ( $2 \mathrm{~d}$ Cir. 1972), in which securities had been resold more than a reasonable time after breach, the court, applying the Code by analogy, awarded market damages under $\$ 2-708(I)$ without any inquiry into the relationship between the market price and the actual resale price.

96 U.C.C. $\$ 2-711$ (emphasis added).

87 U.C.C. \$2-703 (emphasis added). 
The only difference in the Code's treatment of buyers' and sellers' remedies on this issue is the omission of a comment to section 2-708 similar to the comment that damages under section 2-713 are available to a buyer only to the extent the buyer has not covered.98 There is a plausible explanation for this omission, however. Section 2-708 contains not only a market damage formula but also an alternative provision for recovery of profit that is intended to protect the lost volume seller..$^{99}$ A lost volume seller is one who, even though he resells after the buyer's breach, resells to a customer who would have bought another unit from him even if the buyer had not breached. Thus, the lost volume seller has lost one sale because of the buyer's breach and would not be fully compensated by damages based only upon the difference between contract price and resale price under section 2-706. ${ }^{100}$ The Code's drafters could not say in the comment that recovery under section 2-708 was available only to the extent that the seller did not resell because the lost volume seller could resell and still recover under this section. There is no reason, however, that a seller who is not a lost volume seller and who seeks market damages under section 2-708(1) should not be limited to recovery of the difference between contract price and the actual resale price.

While it is possible to reach the proper result under the existing statutory language, the Code should be amended in order to eliminate the possibility of overcompensation. The revisions should make it clear that a buyer who covers cannot obtain market damages based on a market price higher than the actual cover price, and that a seller who resells cannot obtain market damages based on a market price lower than the actual resale price.

Even if the Code is revised, there still remains the problem of determining whether the buyer actually covered or the seller actually resold. The difficulty is particularly acute when the buyer regularly purchases similar goods. ${ }^{101}$ If the buyer does not identify a par-

98 See supra notes $90-91$ and accompanying text.

99 U.C.C. $\$ 2-708(2)$.

100 See infra notes $114-50$ and accompanying text for a more complete discussion of the treatment of the lost volume seller under the Code.

101 Illustrative of the difficulty of proving cover or resale is Jon-T Farms, Inc. v. Goodpasture, Inc., 554 S.W.2d 743 (Tex. Civ. App. 1977). The seller breached a contract to sell grain. The buyer's accountants testified that it was the buyer's normal practice to "maintain its position" by always purchasing sufficient grain to meet its contracts for sale, and that the buyer continued that practice after the seller's breach. The court held that there had been no cover because there was no testimony that the buyer bought specific grain to make up for the specific amount of grain that the seller did not deliver. Id. 750 . 
ticular purchase as the cover purchase, how can the seller prove that tcover was made at a price below the market price? The buyer will have better access to the relevant items of proof and will be in a position, if so inclined, to attempt to disguise a cover transaction. Identifying a cover transaction, even if possible, will normally involve costs to the seller, who often may conclude that the likely difference between cover price and market price does not justify the costs involved in identifying the cover transaction. But this is merely to say that the breaching party may have difficulty proving that there has been a cover or resale; it is not to say that the fact that the aggrieved party covered or resold is insignificant. The breacher should be given an opportunity to prove these facts.

\section{Summary and Suggestions for Revision}

The buyers' remedy provisions of the Code present two significant difficulties. One is the uncertainty as to when a buyer's market damages are to be measured after an anticipatory repudiation. The other problem is the possibility that a buyer who has actually covered might be overcompensated by being permitted to recover market damages under section 2-713 based upon a market price higher than the actual cover price. To deal with the first difficulty, section 2-713 should be revised to provide that a buyer's market damages after an anticipatory repudiation are to be measured as of the end of the commercially reasonable time for awaiting performance or the time that the buyer actually cancels the contract, whichever is earlier. To eliminate the risk of overcompensation when a buyer covers, the Code should be revised to provide that a buyer who has actually covered may not base market damages under section 2-713 on a market price that is higher than the actual cover price.

\section{SELlers' ReMEdies}

\section{A. The Major Problem: Section 2-708(2)}

As indicated previously, few problems of substance have surfaced with respect to the seller's action for the price ${ }^{102}$ or the seller's right to resell and recover the difference between contract price and resale price. ${ }^{103}$ Moreover, section $2-708(1)$, which codifies the traditional common law formula of contract price less market price, is similarly free of major defects, although that provision does raise some problems that will be considered later. ${ }^{104}$ The simplicity of

102 See supra text accompanying notes $42-44$.

103 See supra text accompanying notes 40 \& 90-91.

104 See infra notes 198-211 and accompanying text. 
these provisions is more than offset, however, by the undue difficulty of determining the proper scope and application of section 2-708(2), which provides:

If the measure of damages provided in subsection (1) [the market damages provision] is inadequate to put the seller in as good a position as performance would have done then the measure of damages is the profit (including reasonable overhead) which the seller would have made from full performance by the buyer, together with any incidental damages provided in this Article (Section 2-710), due allowance for costs reasonably incurred and due credit for payments or proceeds of resale. ${ }^{105}$

Two major difficulties arise under this provision. The first problem is determining which sellers are entitled to have their damages measured under the lost profit formula of section 2-708(2). It is fair to say that the test the drafters established in the statutethe lost profit provision applies if the market damages measure of subsection ( 1 ) is inadequate-provides little concrete guidance to a court that must decide a specific case. Moreover, the comment to this subsection does little to clarify the problem and may in fact be entirely misleading. ${ }^{108}$ The second major problem with this provision is determining how the formula is to be employed in various specific circumstances. Neither section 2-708(2) nor its comments give any hint that the formula contained in the section must be applied in radically different ways depending upon the type of situation to which it is being applied. ${ }^{107}$

Given this lack of guidance in the statute, it is fortunate that there are some excellent discussions of section 2-708(2) in the legal literature ${ }^{108}$ which have helped to produce a consensus in the courts, at least in identifying two paradigm situations to which section 2-708(2) applies. The first situation is the case of the lost volume seller-one who resells the goods after the buyer's breach to another buyer who would have bought an additional unit from the seller

105 U.C.C. $\$ 2-708(2)$.

100 See infra text accompanying note 114.

107 See infra notes 138-54 and accompanying text.

108 The leading discussion of sellers' damages is still Harris, A Radical Restatement of the Law of Seller's Damages: Sales Act and Commercial Code Results Compared, 18 Stan. L. Rev. 66 (1965); see also Childres \& Burgess, supra note 37. A recent, thought-provoking article, with a decidedly economic focus, is Goetz \& Scott, Measuring Sellers' Damages: The Lost-Profits Puzzle, 31 Stan. L. Rev. 323 (1979). 
had the original buyer not breached. Because such a seller has lost a sale due to the buyer's breach, the seller will not be made whole if he must credit the buyer with the full resale price or market price zunder sections $2-706$ or 2-708(1). Thus the courts have agreed that, in order to compensate fully the lost volume seller, he must be permitted to recover his lost profits under section 2-708(2)..$^{109}$

The second situation in which the courts ${ }^{110}$ and writers ${ }^{111}$ agree that section 2-708(2) applies is that of the components seller or jobber. In this context, a components seller is one who reasonably stops production ${ }^{112}$ before completing the goods and thus has available for resale only raw materials or partially fabricated components. A jobber for these purposes is a middleman whose only role is to procure finished goods and resell them. Damages are measured under 2-708(2) when this type of seller reasonably decides not to complete or procure the goods after learning of his buyer's breach or repudiation. Because neither the components sellers nor the jobber has finished goods on hand, section 2-708(2) is the only Code damage provision that produces sensible results for such a seller; all of the other damage provisions contemplate the existence of finished goods. ${ }^{113}$

Despite this consensus concerning the application of section 2-708(2) to these two paradigm situations, many significant unresolved issues remain. One such issue is how to determine whether

109 The most frequently-cited case is Neri v. Retail Marine Corp., 30 N.Y.2d 393, 285 N.E.2d 311, 334 N.Y.S.2d 165 (1972). See also Famous Knitwear Corp. v. Drug Fair, Inc., 493 F.2d 251 (4th Cir. 1974); Nederlandse Draadindustrie NDI B.V. v. Grand Pre-Stressed Corp., 466 F. Supp. 846 (E.D.N.Y.), aff'd mem., 614 F:2d 1289 (2d Cir. 1979); Distribu-Dor, Inc. v. Karadanis, 11 Cal. App. 3d 463, 90 Cal. Rptr. 231 (1970); Snyder v. Herbert Greenbaum \& Assoc., 38 Md. App. 144, 380 A.2d 618 (1977). The Second Restatement recognizes the lost-volume principle as applicable to all types of contracts. See RESTATEMENT (SECOND) OF Contracts, $\$ 347$ comment $f \&$ illustration 16,350 comment $d \&$ illustrations 9-10 (student ed. 1981).

110 See, e.g., City of Louisville v. Rockwell Mfg. Co., 482 F.2d 159 (6th Cir. 1973); Holiday Mfg. Co. v. B.A.S.F. Systems, Inc., 380 F. Supp. 1096 (D. Neb. 1974); Industrial Circuits Co. v. Terminal Communications, Inc., 26 N.C. App. 536, 216 S.E.2d 919 (1975); Timber Access Indus. Co. v. U.S. Plywood-Champion Papers, Inc., 263 Or. 509, 503 P.2d 482 (1972); Coast Trading Co. v. Parmac, Inc., 21 Wash. App. 896, 587 P.2d 1071 (1978).

111 See Childres \& Burgess, supra note 37; Harris, supra note 108.

112 The propriety of a decision to stop or complete production is determined under the standards established by $\$ 2-704$. See infra notes 155-60 and accompanying text.

113 Under $\$ 2-706$, the buyer is credited with the resale price of the finished goods. Section 2-708(1) credits the buyer with the market price of those goods at the time and place of tender. Under $\$ 2-709$, the seller receives the full price of the goods but, because the section amounts to specific performance at law, the goods must then be held for the buyer. 
a seller actually is a lost volume seller. A second is whether section 2-708(2) may be used in situations other than the two paradigm cases: may a seller use section 2-708(2) any time the other provisions. give him less than full compensation for the losses incurred? Numerous problems also arise in applying the statutory formula in section 2-708(2) to specific situations. The most serious difficulties are caused by the use of the same formula in both the lost volume and the components seller cases. The type of proof necessary to establish a seller's lost profit is also an important question, and the formula's reference to recovery of profit "including reasonable overhead" raises a number of questions concerning the meaning of "reasonable" overhead and the necessity for distinguishing between profit and overhead. These and other matters involving section 2-708(2) will be considered in the ensuing pages, as will some residual problems involving the traditional market damages remedy of section 2-708(1).

\section{The Lost Volume Seller}

\section{a. Identifying the Lost Volume Seller}

Because the guidance the Code provides is misleading, it is not surprising that courts have had difficulty in identifying lost volume sellers. The comment to section 2-708 states that the provision is "designed to eliminate the unfair and economically wasteful results arising under the older law when fixed price articles were involved. This section permits the recovery of lost profits in all appropriate cases, which would include all standard priced goods." 114 The comment's focus on standard priced goods is misleading. ${ }^{115}$ Consider, for example, a relatively small seller operating in a market dominated by larger sellers. Assume that the small seller prices its goods at a standard price that it cannot raise because of the market dominance of its competitors, and that the small seller is producing at the absolute limit of its plant capacity. If buyer 1 breaches its contract with the seller and the seller resells the goods at the same price to buyer 2, the seller cannot be a lost volume seller even

114 U.C.C. $\$ 2-708$ comment 2.

115 See J. Whirt \& R. Summers, supra note $1, \$ 6-4$, at 226-27. Professors White and Summers hypothesize that the draftsmen focused on "standard priced goods" because in those situations there was no contract-market differential, necessitating another measure of the seller's damages. Id. 226. But cf. Schlosser, Construing UCC Section 2-708(2) to Apply to the Lost-Volume Seller, 24 CASE W. REs. L. REv. 686, 688-89 (1973) (suggesting that the standard price language applies to the lost volume seller, because he cannot lower the price to dispose of all his goods). 
though the goods are standard priced goods. Because of its limited capacity, the seller could not have made a sale to buyer 2 had buyer 1 not breached. Thus, the sale to buyer 2 replaces the original sale to buyer $1-i t$ is a mitigation opportunity. The proceeds of this sale should be credited to the breaching party under either section 2-706 or 2-708(1). Conversely, even if the goods are not standard priced goods, the seller may still be a lost volume seller if the facts show that the sale to buyer 2 would have been made even if buyer 1 had not breached. Thus, despite the language of the comment, whether the goods are standard priced is entirely irrelevent to the determination of whether the seller is a lost volume seller.

To their credit, the courts have not been unduly influenced by the comment's reference to standard priced goods. Instead they have focused on the quite relevant issue whether the seller's supply of the goods in question exceeded the demand for them. Thus, the courts at least have looked at whether the seller had the capacity and the inclination to make an additional sale if the buyer had not breached. ${ }^{116}$ As demonstrated in the preceding paragraph, the capacity to have made an additional sale is an essential element of the lost volume seller's case. The difficulty with even the best of the existing decisions, however, is that they seem to hold that an excess of supply over demand is sufficient in itself to establish that the seller is a lost volume seller. ${ }^{117}$ These decisions have ignored another essential element in establishing lost volume seller statusthat is, whether the resale buyer would have bought from the seller had the original buyer not breached.

116 See, e.g., Nederlandse Draadindustrie NDI B.V. v. Grand Pre-Stressed Corp., 466 F. Supp. 846 (E.D.N.Y.), aff'd mem., 614 F.2d 1289 (2d Cir. 1979); Distribu-Dor, Inc. v. Karadanis, 11 Cal. App. 3d 463, 90 Cal. Rptr. 231 (1970). In two cases, the courts remanded for a determination whether the seller was a lost volume seller, but gave the lower courts no guidance on how to make that determination. Famous Knitwear Corp. v. Drug Fair, Inc., 493 F.2d 251 (4th Cir. 1974); Snyder v. Herbert Greenbaum \& Assoc., 38 Md. App. 144, 380 A.2d 618 (1977). In Neri v. Retail Marine Corp., 30 N.Y.2d 393, 285 N.E.2d 311, 334 N.Y.S.2d 165 (1972), the court of appeals concluded that the case before it was factually similar to an example of a lost volume seller given in a treatise, but the court did not point to specific facts in the case that justified its conclusion. The court cited W. Hawncand, Sales and Bulx Sales 153-54 (1958), for its definition of a lost volume seller, but this treatise focused only on whether the seller had an unlimited supply of the goods in question.

117 See Nederlandse Draadindustrie NDI B.V. v. Grand Pre-Stressed Corp., 466 F. Supp. 846 (E.D.N.Y.), aff'd mem., 614 F.2d 1289 (2d Cir. 1979); Distribu-Dor, Inc. v. Karadanis, 11 Cal. App. 3d 463, 90 Cal. Rptr. 231 (1970); see also Childres \& Burgess, supra note 37 , at $880-81$, 886 (focusing solely on whether the seller has fewer customers than he can supply). 
To illustrate this point, consider a boat dealer who contracts to sell a twenty-foot speedboat to buyer 1 , who breaches the contract by refusing to take delivery of the boat. The seller then resells the boat, which is the only twenty-foot speedboat he presently has available, to buyer 2, who walked into the seller's showroom the day after the seller learned of buyer l's breach. Assume further that the manufacturer was producing many similar boats and that, over a reasonably short time, the seller could have obtained as many twenty-foot speedboats as he could resell. In a gross sense, then, there is an excess of supply over demand. But assume further that buyer 2 needs a boat within a day or two, and that buyer 2 would have bought a twenty-foot speedboat from another dealer had the seller not had one available for immediate delivery. ${ }^{118}$ In this situation, it is clear that the seller would not have made the sale to buyer 2 had buyer 1 not breached, and thus the seller is not a lost volume seller. ${ }^{119}$

Courts that focus solely on whether there was an excess of supply over demand may not see the possibility that a seller with extra goods still may not be able to meet the needs of particular buyers. Those courts may improperly overcompensate a seller by classifying him as a lost volume seller. In order to make an accurate determination of lost volume status, then, one must examine not only the seller's general capacity to make additional sales but also the needs of the particular resale buyer. It must be established that this particular buyer probably would have bought from the seller even if the original buyer had not breached. ${ }^{120}$

118 An obvious variation would occur if the boat had some factory-installed optional equipment upon which buyer 2 insisted. If not for the breach, the seller would not have a conforming boat available for sale to buyer 2 . Because the seller could not have made both sales, he is not a lost volume seller in this case.

119 It would be possible to view this situation as merely a special case of demand exceeding supply or the seller's not having the capacity to make a second sale. But focusing on the excess of supply over demand, as the courts do, tends to emphasize the seller's capacity in general. This approach does not place sufficient importance on the needs of the particular resale buyer or upon whether that buyer in fact would have purchased from the seller had the original buyer not breached.

120 Professor Harris recognized this consideration several years ago when he stated that three conditions must be met to establish lost volume status: (1) the resale buyer would have been solicited by the seller had there been no breach; (2) the sale would have been made to the resale buyer, and (3) the seller could have performed the additional contract. Harris, supra note 108 , at $82-83$.

Professor Harris's last condition essentially raises the excess capacity question that the courts have been considering. The first condition has not been mentioned explicitly in the decisions, but this condition normally would be met if the seller sells to a regular customer or to one who, as is often the case, initially contacts the seller because of the seller's reputation or general advertising. If the seller makes special sales or advertising efforts to resell the goods after the buyer's breach, proving 
Some commentators have suggested that because a substantial majority of merchant sellers will be lost volume sellers, the primary seller's remedy should be section 2-708(2) rather than the resale damages provision of section 2-706. ${ }^{121}$ Despite the need for a stricter standard for determining whether a seller is a lost volume seller, I agree with the suggested primacy of section 2-708(2). ${ }^{122}$ It seems to me likely that, at least with respect to relatively standard goods, most merchant sellers will be lost volume sellers in that they probably will have excess capacity and probably will resell to a buyer who otherwise would have bought from them. Thus, at least in theory, section 2-708(2) will be the appropriate remedy for many merchant sellers. ${ }^{123}$

In a very interesting article, however, Professors Goetz and Scott recently have attempted to use economic theory to show that even a merchant seller is unlikely to have lost volume as a result of a buyer's breach. ${ }^{24}$ One foundation of the Goetz and Scott argument is the accepted proposition that economically efficient entities, whether they be manufacturers or retailers, attempt to operate at a

that this condition is fulfilled may be difficult. Likewise, if the seller decided to go out of business before learning of the buyer's breach or if the seller was not in the business of selling these goods, this first condition would not be met. In these circumstances, the seller would not have solicited additional buyers had the original buyer not breached. Id. 82-83. It is by ignoring Harris's second condition (whether a sale would have been made to the particular resale buyer) that the courts have increased the risk of overcompensating the seller by improperly classifying him as a lost volume seller.

121 Childres \& Burgess, supra note 37, at 880-82. For an indication that the drafters of the Code thought that resale damages of $\$ 2-706$ would be the seller's primary remedy, see U.C.C. \$2-704 comment 1 .

122 Another reason for the primacy of this section is that it covers another common commercial situation-the components seller or jobber. See supra notes 110-13 and accompanying text.

123 The primacy of $\$ 2-708(2)$ may only be theoretical. Factors such as the difficulty of proving lost profit, the likelihood of more protracted litigation, and the increased costs of litigation may induce one who probably is a lost volume seller to forego recovery under $\$ 2-708(2)$ and settle for a lesser recovery under $\$ 2-706$. Cf. Shanker, The Case for a Literal Reading of UCC Section 2-708(2) (One Profit for the Reseller), 24 CASE W. REs. L. REv. 697, 707-08 (1973) (arguing that one reason that lost profit recovery should not be allowed for lost volume seller is because of the difficulties of proof). According to Professor Shanker, proving that a seller lost a sale because of the original buyer's breach necessitates proof "not of what actually happened, but rather, of what might have happened." Id. 708.

124 Goetz \& Scott, supra note 108, at 330-54. A similar argument was made years earlier in Note, $A$ Theoretical Postscript: Microeconomics and the LostVolume Seller, 24 Case W. Res. L. Rev. 712 (1973), reprinted in A. Kronman \& R. Posner, The Economacs of Contract Law 213 (1979). See also Shanker, supra note 123, at 704-07. Professors Goetz and Scott cite and criticize this earlier student Note. See Goetz \& Scott, supra note 108, at 331 n.22. 
level of output where marginal cost ${ }^{125}$ equals marginal revenue. ${ }^{120}$ Economic theory also posits that these efficient sellers are likely to be producing at a level where marginal costs are rising as additional units are produced or sold, and that marginal revenue is likely to be falling, or at best remaining constant, because the increased supply caused by additional production or sales will cause the market price to fall. ${ }^{127}$ Based upon these traditional economic concepts, Goetz and Scott argue that, even if the seller had the capacity to do so, a seller operating at the level where marginal cost equals marginal revenue would not have produced the additional goods to sell to buyer 2 if buyer 1 had not breached. In a world of rising marginal costs and static or declining marginal revenue, it would not have been efficient for the seller to produce or obtain additional goods to sell to buyer 2 because the marginal cost of those goods. would exceed the marginal revenue received from their sale and the seller would have lost money. Thus, Goetz and Scott suggest that the sale to buyer 2 is a sale that the efficient seller normally would not have made, and therefore the seller is not a lost volume seller. ${ }^{128}$

Like most economic theories, the Goetz and Scott analysis depends upon assumptions that are not always true. In this case, the assumptions are (1) that marginal costs are rising such that the production of additional goods for sale to buyer 2 will cause marginal costs to exceed marginal revenue; (2) that the seller knows this fact, and (3) that the seller will act rationally by not making an additional sale to buyer 2. It is likely that in many situations these assumptions may be incorrect. First, as even Goetz and Scott recognize, a seller's marginal costs often will not increase significantly with each additional unit of production; rather, marginal costs often will remain constant within fairly substantial variations in output. ${ }^{129}$ The same can be said of marginal revenue. If a seller is operating in a range of constant marginal costs and marginal revenue, there is

125 Marginal cost is the additional cost incurred to produce an additional unit of output. P. SAMuelson, Economics 428, 442 (11th ed. 1980).

126 Marginal revenue is the additional revenue produced by the sale of an additional unit of output. Id. 466. Profit-maximization occurs at the point where marginal revenue equals marginal cost. Id. 467 .

127 See, e.g., A. Alchinan \& W. Allen, Exchange and Production 186-87 (2d ed. 1977); P. SaMuelson, supra note 125, at 428, 442.

128 Goetz \& Scott, supra note 108, at 333-35. See also Shanker, supra note 123, at 704-07; Note, supra note 124.

129 Goetz \& Scott, supra note 108, at $335-48$. They repeatedly note that "marginal costs for many sellers may be constant over wide ranges in output; thus the cost effect of a given breach is always an empirical question." See, e.g., id. 348. 
no economic disincentive to making the additional sale to buyer $2 . .^{130}$ Moreover, even if marginal costs would exceed marginal revenue on the additional sale, there is no assurance that the seller's cost accounting system would be sufficiently accurate in the short run to have permitted the seller to discover the cost increase in time to decide not to make an additional sale. Absent such accurate marginal cost data, my guess is that the inclination of most business people would be to make as many sales as they have the capacity to make.131

Having said all of this, I should emphasize that my differences with Goetz and Scott are more a matter of emphasis than of principle. I do not quarrel with the proposition that marginal costs may be increasing such that the seller would not have made an additional sale had the buyer not breached. For example, if the original sale involved a large quantity, making it more likely that an additional sale would substantially increase marginal costs, Goetz and Scott may well be right. My principal dissent is from the proposition that increasing marginal costs make it likely that most sellers would not be lost volume sellers. Whether one is a lost volume seller is ultimately a matter of proof. Goetz and Scott seem to suggest that there should be a presumption that the seller is not a lost volume seller, even though a seller has the capacity to make an additional sale and even though the resale buyer probably would have bought from the seller had the original buyer not breached. They presume that the resale merely replaces the original sale because, in part, of the assumed rising marginal costs. ${ }^{132}$ For the reasons stated, I would engage in no such presumption. Instead, once the seller shows that he had the capacity to make an additional sale and that the resale buyer probably would have bought from him anyway, I would place the burden of proof on the breaching buyer to show that the seller would not have made an additional sale because of rising marginal costs. ${ }^{133}$

130 In the classic case of a car dealer, for example, the sale to a second buyer after the original buyer breaches should not be presumed to be a replacement sale. The car dealer can often get as many cars as he needs for customers. And, over the relevant ranges of the dealer's marginal cost and revenue curves, the dealer's costs and profits may be constant. Usually, the manufacturer will supply cars at a fixed price and the dealer will charge a constant price. Contrary to Goetz and Scott's assumptions, it often would be efficient for the dealer to make the additional sale.

131 The likelihood that the seller would make the additional sale makes him a lost volume seller entitled to have his damages measured under $\$ 2-708(2)$. Whether the seller has lost any profit, or how much profit the seller has lost, are matters of proof. The problems of proving lost profit in a world of rising marginal costs are discussed later. See infra notes 191-97 and accompanying text.

132 See Goetz \& Scott, supra note 108, at 329, 348-52.

133 Goetz and Scott suggest a similar technique themselves in a different context when they advocate permitting a seller to prove profit plus overhead under 
Goetz and Scott suggest another reason that a seller normally would not be a lost volume seller: that the buyer's breach will cause an increase in demand for the seller's product, offsetting any losses suffered because of the buyer's breach. ${ }^{334}$ They argue that the buyer would have resold the goods if she had not breached, because the breach indicates that the buyer does not want the goods. They further suggest that if the buyer did resell, it is likely-that the sale would be to someone who otherwise would have bought from the seller. Because the buyer who breaches can no longer resell the goods, that breach will permit the seller to make an additional sale to a customer who otherwise would have bought from the breaching buyer. ${ }^{135}$

Again, my disagreement is not with the possibility that a breach might increase the demand for the seller's goods, but rather with the proposition that this is the most likely result of a breach. Although it is always possible that the buyer would have resold the goods quickly if she did.not breach, it seems at least equally plausible that the nonbreaching buyer would have decided to keep the goods. Often, one of the major reasons a buyer breaches is not that she no longer wants the goods, but rather that she has obtained a more attractive deal from another seller and decides to get out of the original contract. If a buyer so tempted already has accepted the goods from the original seller, however, it seems quite likely that she will decide to keep the goods because the costs and risks associated with resale will outweigh the initial attractiveness of the other seller's offer. ${ }^{130}$ Furthermore, even if the buyer would have resold had she not breached, it is not at all certain that she would have resold to someone who otherwise would have bought from the seller. The new purchaser may well be someone who is seeking a price advantage that could not be obtained from the original seller, or who normally would have purchased used goods, or who would have bought from one of the seller's competitors. In short, the potential buyers on resale by the breacher may be considerably different from those who would purchase at retail from a dealer or manufacturer. Thus, while it is possible that a buyer's breach would permit a seller to make an

$\$ 2-708(2)$ by contract price less average variable cost, leaving the buyer the burden of establishing that the seller's marginal cost exceeded the average variable cost. Id. 365-68. See infra note 197.

134 Goetz \& Scott, supra note 108, at 340-46.

$135 \mathrm{Id}$.

136 Having accepted the goods, a buyer is liable for their price unless the buyer is able to revoke his acceptance. See U.C.C. $\$ 2-709$. 
additional sale by eliminating the buyer as a competing seller, such a result is far from certain. ${ }^{137}$ Of course, courts should be sensitive to that possibility. In my judgment, however, the chance that the buyer's breach would actually permit the seller to make an additional sale in this way is sufficiently remote that the breaching buyer should bear the burden of ultimate persuasion on this issue.

\section{b. Measuring Damages for the Lost Volume Seller}

After concluding that a seller is in fact a lost volume seller, the next problem is to determine damages under the formula of section 2-708(2). Largely as a result of the writings of Professor Harris, ${ }^{138}$ it is now widely recognized that a faithful application of section 2-708(2)'s formula ${ }^{139}$ to the lost volume seller produces an incorrect result. To illustrate, assume that the seller is a lost volume seller, that the contract price was $\$ 5,000$, that the variable costs to perform the contract would have been $\$ 4,200$, and that profit and overhead together were $\$ 800$. Assume further that the seller resells the goods for $\$ 5,000$, that no incidental damages were incurred, and that the breaching buyer had paid nothing to the seller. A literal application of the statutory formula produces the following result:

$$
\begin{aligned}
& \text { profit \& } \\
& \text { overhead } \\
& \$ 800+\begin{array}{c}
\text { incidental } \\
\text { damages }
\end{array}+\begin{array}{c}
\text { costs } \\
\text { incurred }
\end{array}-\text { payments }-\begin{array}{c}
\text { proceeds } \\
\text { of resale }
\end{array} \\
& \quad 0+\$ 4,200-0
\end{aligned}
$$

This result is precisely the same as would obtain if the seller were forced to measure damages under the contract price less resale price formula of section 2-706, and it obviously does not award the lost volume seller his lost profit.

Professor Harris showed the way out of this morass by arguingthat when section 2-708(2) is applied to a lost volume vendor, the "costs incurred" and "proceeds of resale" parts of the formula should

137 Goetz and Scott, at one point, do recognize the possibility that the buyer would choose to retain the goods or that the resale might be to one who would not have bought from the seller. They give only brief attention to these possibilities, however. Goetz \& Scott, supra note 108, at 344-45.

138 See Harris, supra note 108, at 93-109; see also Harris, A General Theory for Measuring Seller's Damages for Total Breach of Contract, 60 Mrch. L. Rev. 577 (1962).

139 The formula in $\$ 2-708(2)$ is: "the profit (including reasonable overhead) which the seller would have made from full performance by the buyer, together with any incidental damages provided in this Article (Section 2-710), due allowance for costs reasonably incurred and due credit for payments or proceeds of resale." U.C.C. $\$ 2-708(2)$. 
be ignored. ${ }^{140}$ In the previous example, such a construction would produce the correct result-an award of $\$ 800$ to compensate the lost volume seller for his lost profit and overhead. ${ }^{141}$ Fortunately, all of the reported decisions considering the question have followed Professor Harris's advice and thus have reached appropriate results. ${ }^{142}$ In terms of normal methods of statutory interpretation, however, it is not easy to justify such a creative reading of the statute. ${ }^{143}$ If pressed for a justification other than that the drafters could not have meant what they seem to have said, one might point to the provision's language calling for "due allowance" for costs incurred and "due credit" for proceeds of resale. ${ }^{144}$ This language is less absolute than that found in the other Code remedy provisions, ${ }^{145}$ supporting the inference that the drafters thought there might be some instances in which it would not be appropriate to include costs and proceeds. Obviously, the situation of the lost volume seller is one such situation. ${ }^{146}$

140 Harris, supra note 108, at 105-06; see also J. WhHTE \& R. SuMMERs, supra note $1, \$ 7-9$; cf. $R$. Nordstrom, HANDBOoK of THE LAw of SALES $\$ 177$, at 541 (1970) (arguing that proceeds of resale language only refers to sales on component parts, not completed units); Schlosser, supra note 115 , at $691-96(\$ 2-708(2)$ (profit that seller would have made from performance includes profit on both sales so proceeds on resale can be credited)).

141 The result would be the same even if the resale price were $\$ 4,000$ or $\$ 6,000$, despite a suggestion by Professor Harris to the contrary. See Harris, supra note 108, at 82. Because the seller is a lost volume seller, the resale is one which the seller presumably would have made even if there had been no breach. Thus, the resale price is irrelevant to determining the loss that the seller incurs because of the breach.

142 See Famous Knitwear Corp. v. Drug Fair, Inc., 493 F.2d 251 (4th Cir. 1974); Nederlandse Draadindustrie NDI B.V. v. Grand Pre-Stressed Corp., 466 F. Supp. 846 (E.D.N.Y.), aff'd mem., 614 F.2d 1289 (2d Cir. 1979); Snyder v. Herbert Greenbaum \& Assoc., 38 Md. App. 144, 380 A.2d 618 (1977); Neri v. Retail Marine Corp., 30 N.Y.2d 393, 285 N.E.2d 311, 334 N.Y.S.2d 165 (1972); see also J. WhITE \& R. SUMmers, supra note 1, \$7-13, at 285.

143 White and Summers take the position that "[g]ross errors of the kind here committed by the drafters call for extraordinary solutions." J. WHrTE \& R. SUnsMERS, supra note $1, \$ 7-13$, at 285 .

144 U.C.C. $\$ 2-708(2)$.

145 Compare U.C.C. $\$ \$ 2-706,2-708(1), 2-712(2), 2-713$ with U.C.C. $\$ 2-708(2)$.

146 There is some support in the drafting history of $\$ 2-708(2)$ for ignoring the costs and proceeds language in the context of a lost volume seller. That language, added in 1955, was explained as follows: "The main purpose of the change is ... to clarify the privilege of the seller to realize junk value when it is manifestly useless to complete the operation of manufacture." AMERICAN LAW INSTITUTE \& National Conference of Commissioners of Uniform State Laws, Supplement Number One to the 1952 Offrcial Draft of Text and Comments of the Uniform Commerctal Code 14 (1955). 
There are some circumstances, however, in which the "costs incurred" and "resale proceeds" parts of the formula should be applied to parts of a transaction involving a lost volume seller. In the previous hypothetical, for example, assume that $\$ 1,000$ of the $\$ 4,200$ variable cost was the cost of acquiring optional equipment that the buyer ordered. Assume further that the seller resold the goods for $\$ 4,000$ to a resale buyer who did not want the optional equipment and that the seller had to resell the optional equipment to a parts dealer for $\$ 500$. The acquisition and resale of the optional equipment produces an additional net out-of-pocket loss of $\$ 500$ for which the seller must be compensated if he is to be made whole. The question, then, is how to achieve this result under section 2-708 (2). One possibility would be to treat the loss as incidental damages, but section 2-710's definition of incidental damages focuses on costs that are incurred after the breach that would not be incurred but for the breach; ${ }^{147}$ the cost of the optional equipment in this example was incurred before the breach. A better solution is to treat the $\$ 1,000$ cost of the optional equipment as a "cost incurred" and the $\$ 500$ proceeds as "proceeds of resale." The effect of this interpretation is to treat "costs incurred" as covering only "wasted costs"-those incurred for the performance of the breached contract and not recouped in the resale ${ }^{148}$-and to treat "proceeds of resale" as including only proceeds from a sale that would not have been made but for the breach. ${ }^{149}$ This revised interpretation of "costs incurred" and "proceeds of resale" in the lost volume context is consistent with the interpretation of those terms in other contexts, such as that of the component seller who reasonably stops production and resells the parts on hand for their salvage value.150

147 U.C.C. $\$ 2-710$ provides: "Incidental damages to an aggrieved seller include. any commercially reasonable charges, expenses or commissions incurred in stopping delivery, in the transportation, care and custody of goods after the buyer's breach, in connection with return or resale of the goods or otherwise resulting from the breach."

148 Examples of other "wasted costs" for which a lost volume seller should be compensated include costs of preparing goods for delivery to the buyer if those costs had to be incurred again before a second sale, and any sales commissions paid on the initial sale that were not recoverable after the breach.

140 Obviously, the resale of the optional equipment is a sale that would not have been made had the buyer not breached, and thus the buyer clearly is entitled to credit for those proceeds. Again, Professor Harris was the first to see the possibility that the last part of the $\S 2-708(2)$ formula might be used with respect to some aspects of a transaction involving a lost volume seller. See Harris, supra note 108 , at 106.

150 In the component seller context, the last part of the formula is properly used because the costs are not otherwise recouped and the resale is not one that would have been made absent the breach. See supra note 146 \& infra 153-54 and accompanying text. 
Although creative interpretation can produce correct results under the present version of section $2-708(2)$, the section should be revised. One of the purposes of the Code was to make the law clearer and more accessible, ${ }^{151}$ and section 2-708(2) in its present form certainly does not serve that purpose. Some suggestions concerning possible revisions will be offered below, ${ }^{152}$ after we have considered other contexts in which section 2-708(2) might be applicable and examined some difficulties in measuring damages under the formula contained in the section.

\section{The Components Seller or Jobber}

The second paradigm situation in which it is agreed that section 2-708(2) applies is that of the components seller who reasonably stops production or the jobber who reasonably decides not to acquire goods intended for the buyer after learning of the buyer's breach or repudiation. ${ }^{153}$ In this context, there is no difficulty with the formula of section 2-708(2): the entire formula is used, including "costs incurred" and "proceeds of resale," because any costs incurred are wasted except to the extent that the components produced can be sold for salvage, and any such salvage sales are ones that would not have been made if the buyer had not breached. ${ }^{154}$

One important issue in these situations is whether the decision to stop work was reasonable. Section 2-704(2) establishes a "reasonable commercial judgment" standard by which to evaluate such decisions. ${ }^{155}$ Despite the vagueness of the standard, a more precise criterion would not be appropriate in view of the myriad factual situations that could arise. The Code does provide some guidance for the application of this provision in a comment that makes it clear that the reasonableness judgment should be based upon the

151 See, e.g., Llewellyn, Why a Commercial Code?, 22 TENN. L. REv. 779, 779-80 (1953).

152 See infra notes 212-27 and accompanying text.

153 See supra notes 110-13 and accompanying text.

154 See, e.g., American Metal Climax, Inc. v. Essex Int'l Inc., 16 U.C.C. Rep. Serv. (Callaghan) 101 (S.D.N.Y. 1974); E-Z Roll Hardware Mfg. Co. v. H \& H Prods. \& Finishing Corp., 4 U.C.C. Rep. Serv. (Callaghan) 1045 (N.Y. App. Div. 1968); Industrial Circuits Co. v. Terminal Communications, Inc., 26 N.C. App. 536, 216 S.E.2d 919 (1975); see also J. Whrte \& R. SuMMERS, supra note 1, $\$ 7-13$, at 286-87; Harris, supra note 108, at 104 .

135 U.C.C. $\$ 2-704(2)$ provides:

Where the goods are unfinished an aggrieved seller may in the exercise of reasonable commercial judgment for the purposes of avoiding loss and of effective realization either complete the manufacture and wholly identify the goods to the contract or cease manufacture and resell for scrap or salvage value or proceed in any other reasonable manner. 
facts at hand when the decision to stop or to complete was made.158 Moreover, courts have propounded the shared view that the inquiry under this provision should focus on whether the decision made was likely to increase or to reduce the buyer's liability for damages. ${ }^{157}$ Other factors, such as a seller's need to keep his production line going or to retain key employees, of course, also may be relevant. These considerations could justify a decision to continue production even though doing so would likely increase the buyer's damage liability. ${ }^{158}$ By placing the burden on the buyer to demonstrate the unreasonableness of any decision to complete production, the comment to section 2-704 also favors a decision to complete. ${ }^{159}$ This allocation of burden is consistent with the commonsense assumption that the resale of completed goods normally will be more efficient than will the sale of unfinished goods for scrap. ${ }^{160}$

Section 2-704 does need to be revised in order to clarify the Code's sanctions against a seller who makes an unreasonable decision to stop work. Neither section 2-704 nor its comments explicitly discuss the consequences of unreasonable action. The

${ }^{156}$ See U.C.C. $\$ 2-704$ comment 2 .

157 See, e.g., Detroit Power Screwdriver v. Ladney, 25 Mich. App. 478, 181 N.W.2d 828 (1970) (stopping production justified if goods are specialized and have no reasonably accessible market); Industrial Circuits Co. v. Terminal Communications, Inc., 26 N.C. App. 536, 216 S.E.2d 919 (1975) (stopping production justified when there is no ready market for completed goods so that completion would increase damages); Timber Access Indus. Co. v. U.S. Plywood-Champion Papers, Inc., 263 Or. 509, 503 P.2d 482 (1972) (seller must complete unless costs of production will be likely to exceed market price).

158 See, e.g., Northern Helex Co. v. United States, 455 F.2d 546 (Ct. Cl. 1972). In that case, the court held that it was reasonable for the seller to have continued production of helium despite the lack of a ready resale market, because helium was a natural byproduct of the otherwise profitable production of natural gas.

159 "[T] $]$ he seller is given express power to complete manufacture . . . unless the exercise of reasonable commercial judgment . . . makes it clear that such action will result in a material increase in damages. The burden is on the buyer to show the commercially unreasonable nature of the seller's action in completing manufacture." U.C.C. $\$ 2-704$ comment 2. For a decision relying in part on this allocation of burden, see Northern Helex Co. v. United States, 455 F.2d 546 (Ct. Cl. 1972).

160 Courts and commentators have long recognized that completing production will often be more efficient than the sale of unfinished goods. See, e.g., Buchman v. Millville Mfg. Co., 17 F.2d 983, 985 (2d Cir. 1927); Speidel \& Clay, Seller's Recovery of Overhead Under UCC Section 2-708(2): Economic Cost Theory and Contract Remedial Policy, 57 ConNel. L. Rev. 681, 690 n.33 (1973).

Placing the burden on the buyer also is consistent with viewing the decision to stop or to complete production as essentially a question concerning mitigation of damages, on which the defendant normally bears the burden. Mitigation principles also would suggest that the buyer should bear the burden of showing the unreasonableness of a decision to stop production, an issue that the comment does not address directly. Even if the burden is also on the buyer in the stopped production context, the general likelihood of increased realization if goods are completed should justify placing a somewhat heavier burden on the buyer when the seller chooses to complete production than when the seller stops. 
comments' concentration solely on the reasonableness of a seller's decision to complete could lead one to conclude that a seller would never have a duty to complete and could always stop production. ${ }^{101}$ Such a narrow interpretation of section 2-704, however, would encourage economically inefficient behavior and would contravene general principles of mitigation of damages. The more sensible interpretation is that if a seller acts unreasonably in stopping production, the seller cannot recover more damages than he would have suffered if he had reasonably completed the goods. ${ }^{162}$ At least one court considering this issue has stated that in such a situation the contract-market differential is the appropriate damage measure. In Detroit Power Screwdriver v. Ladney, ${ }^{163}$ after the buyer breached, the seller did not complete production of the machine that the buyer had ordered. The court stated that if there was no resale market for the completed machine, the seller's damages could be measured under section 2-708(2). ${ }^{104}$ If, however, the machine was not a "specialty good" and a resale market existed, the seller's decision to stop production would be unreasonable. The seller, then, would be relegated to market damages under section $2-708(1) .{ }^{165}$ Thus, when there is an available market in which the completed goods can be resold, the Code should encourage the seller to mitigate damages by completing and reselling the goods. ${ }^{160}$ Although, as Detroit Power Screwdriver indicates, the existing Code is susceptible to such an interpretation, section 2-704 should be revised to eliminate any uncertainty.

While the market damages measure will often be the appropriate remedy for the seller who unreasonably fails to complete production, the lost profit provision may sometimes be appropriate

161 Such a view would be consistent with some pre-Code law and would understand the purpose of $\$ 2-704$ to be only to permit completion. If this was the drafters' intention, this would explain the Code's focus on reasonable completion. Permitting completion represents a change from the Uniform Sales Act, which imposed no duty to complete and which provided that a plaintiff never could recover more damages than those which would have been suffered if work had been halted immediately after learning of the buyer's repudiation. Uniform Sales Act $\$ 64(4)$.

162 See J. Whrte \& R. SuMMars, supra note 1, \$7-14, at 291; Goetz \& Scott, supra note 108, at 357.

16325 Mich. App. 478, 181 N.W.2d 828 (1970).

164 Id. at $488-89,181$ N.W.2d at 833-34.

165 Id. at 489,181 N.W.2d at 834 .

166 Some courts deciding this issue under common law principles before the Code was enacted reached the same result. See, e.g., W.R. Grace \& Co. v. Nagle, 275 F. 343 (2d Cir. 1921); Kincaid v. Price, 18 Colo. App. 73, 70 P. 153 (1902); Garfield \& Proctor Coal Co. v. New York, N.H. \& H.R.R., 248 Mass. 502, 143 N.E. 312 (1924). 
for estimating the damages on completion. It is possible that if the seller had completed and resold the goods, he would have resold them to a buyer who otherwise would have made an additional purchase from the seller. If the seller can establish that he probably would have been a lost volume seller if he had completed the goods, ${ }^{167}$ he should be entitled to have his damages measured under section 2-708(2) as a lost volume seller. He thus woúld be entitled to recover lost profit and overhead but not his costs incurred before stopping production, because the "costs incurred" pàrt of the formula is not ordinarily applicable to lost volume sellers. ${ }^{168}$ Moreover, those costs presumably would have been recouped on resale after completion had the seller acted reasonably and completed production.

\section{Other Possible Applications of Section 2-708 (2)}

Professors White and Summers argue that section 2-708(2) should not be limited to lost volume sellers, component sellers, and jobbers. According to them, the section should be available to any seller who would not otherwise be fully compensated under section 2-706 or 2-708(1). Specifically, they assert that section 2-708(2) should be available (1) to a seller who resells completed goods but is not a lost volume seller and for some reason is not entitled to have damages measured by the contract price-resale price differential under section 2-706 and (2) to a seller who holds completed goods that are unsold at the time of trial.169 White and Summers further assert that in these circumstances the entire formula of section 2-708(2) should be used because the seller is not a lost volume seller. The buyer should be credited with the actual resale proceeds or the proceeds that would have been received from a reason-

107 I have argued that, in order to determine lost volume seller status, a court should look carefully at the actual resale purchaser to determine whether that buyer probably would have bought from the seller even if the original contract had not been breached. See supra notes 117-20 and accompanying text. If the seller has not completed production and has not resold the goods, it obviously is impossible to consider an actual resale buyer. To establish that he probably would have been a lost volume seller if he had completed the goods, the seller should have to show both that he would have had the capacity to make the additional sales and that it is probable that any resale purchaser would have been someone who otherwise would have bought from the seller. The seller might satisfy his burden on these points by showing, for example, that he had fewer customers than he could supply at the prevailing price and that he had a ready supply of reasonably similar goods available for sale. See Childres \& Burgess, supra note 37 , at 877,879 :

108 See supra notes $140-50$ and accompanying text; Childres \& Burgess, supra note 37 , at $879-80$.

169 J. WhITE \& R. Surdmers, supra note $1, \$ 7-11$, at 279-81. 
able resale, whichever is greater. ${ }^{170}$ The recovery that they propose is essentially the same as the contract price less resale price formula of section 2.706 except that a putative "reasonable resale price" is substituted for the actual resale price.172 The basic thrust of the White and Summers argument, then, is to permit a seller who does not make a reasonable resale to avoid the risk, which is particularly acute in a falling market, of having damages measured under section 2-708(1) by contract price less market price at the time and place of tender.

The one court that has explicitly considered the matter has rejected the White and Summers argument because, in the court's judgment, permitting a seller to use section 2-708(2) in this situation would undercut the policies of section 2-706.172 I agree with the court. Section 2-706 was intended to protect sellers from the vagaries of market price determinations by permitting them to measure damages by the actual proceeds of a reasonable resale. The intent apparently was to encourage resale as the primary seller's remedy ${ }^{173}$ and to remit those who did not make a proper resale to the traditional market damages measure of section 2-708(1). ${ }^{174} \mathrm{Al}$ though a seller who fails to make a reasonable resale thus absorbs a loss in a falling market, this sanction seems appropriate as an incentive to make a reasonable resale, particularly because the criteria for a reasonable resale in section 2-706 are not overly onerous. ${ }^{175}$ White and Summers, by offering a seller the option of crediting the buyer with the proceeds of a putative reasonable resale under section 2-708(2), reduce the incentive for complying with section 2-706.

170 Id. 280.

171 The formula of $\$ 2-708(2)$, as White and Summers would revise it in this situation, would be: (profit + overhead) + incidental damages + costs incurredproceeds of a reasonable resale. Given that contract price $=$ profit + overhead + costs incurred, contract price can be substituted into the formula, leading to the following: contract price + incidental damages-proceeds of a reasonable resale. The result is a slightly revised version of the formula in \$2-706.

172 Cole v. Melvin, 441 F. Supp. 193, 209 (D.S.D. 1977). But see Snyder v. Herbert Greenbaum \& Assoc., 38 Md. App. 144, 380 A.2d 618, 626 (1977) (dictum).

173 See U.C.C. $\$ 2-704$ comment 1.

174 U.C.C. $\$ 2-706$ comment 2 states: "Failure to act properly under this section deprives the seller of the measure of damages here provided and relegates him to that provided in Section 2-708." Although the comment does not refer specifically to $\$ 2-708(1)$, there is no hint in the comments to $\$ 2-708$ that the drafters intended that anything other than the traditional market damage measure would apply in this situation.

175 The basic criterion is that every aspect of the sale must be commercially reasonable. U.C.C. $\$ 2-706(2)$. In addition, there are requirements for giving the buyer notice of the resale that differ depending on whether the resale is at a public or private sale. U.C.C. $\$ \$ 2-706(3)-(4)$. 
Moreover, the White and Summers position would treat a seller more favorably than a buyer is treated in the analogous situation. A buyer who fails to make a reasonable cover under section 2-712 clearly is remitted to section $2-713$, and under that section damages are measured by the difference between contract price and the market price at the time the buyer learned of the breach; there is no flexibility for a buyer to measure damages by the price of a putative reasonable cover. ${ }^{176}$

With respect to a seller who does not resell, the second case in which White and Summers argue section -2-708(2) should apply, section 2-708(1) still is, in my judgment, the appropriate provision under which to measure damages. If a seller chooses to retain goods for his own use rather than to attempt a resale, the market price at the time and place of tender is the appropriate measure of damages because that is the market in which the seller most probably would have resold had he chosen to do so. White and Summers suggest that section 2-708(2) should be extended to protect a seller who attempted to resell but reasonably held the goods until trial waiting for the market to improve. ${ }^{177}$ If in fact the seller acted reasonably in holding the goods until trial, however, he should be entitled to the price under section 2-709 on the ground that the goods cannot be resold at a reasonable price; ${ }^{178}$ if the market is so weak that the seller could not make a reasonable sale before trial, he should be able to shift the risk of realizing the value of the goods in that market directly to the buyer through an action for the price. On the other hand, if the seller could have resold at some reasonable

176 The buyers' market damage provision of $\$ 2-713$ does provide, however, more flexibility with respect to the time at which damages are measured than does the sellers' market damage formula of $\$ 2-708(1)$, under which the market price must be measured at the date of tender. Later in this Article I recommend that the sellers' market damages measure be revised to be more consistent with the provision applicable to buyers. See infra notes 207-11 and accompanying text.

177 J. WhITE \& R. SUMmers, supra note 1, \$7-11, at 279-81.

178 U.C.C. $\$ 2-709$ (1) provides, in pertinent part:

When the buyer fails to pay the price as it becomes due the seller may recover, together with any incidental damages under the next section, the price

(b) of goods identified to the contract if the seller is unable after reasonable effort to resell them at a reasonable price or the circumstances reasonably indicate that such effort will be unavailing.

In Nuemiller Farms, Inc. v. Cornett, 368 So. 2d 272 (Ala. 1979), the court improperly employed $\$ 2-708$ (2) to compensate a seller of potatoes whom the jury found was unable to resell. In applying $\$ 2-708(2)$, the court gave no offset for the resale value of the potatoes. This is obviously a situation in which the seller would have been entitled to the price under $\$ 2-709$. 
price, then he should have done so, and the risk of having market damages measured at the time of tender under section 2-7.08(1) should be permitted to remain as an incentive to appropriately prompt resales.

White and Summers also assert that there may be situations in which a seller could be compelled to measure damages under section 2-708(2) rather than under section 2-708(1).178 Consider a seller with a $\$ 10,000$ contract who learns of the buyer's repudiation and reasonably ceases work before incurring any costs. Assume that the cost of production would have been $\$ 9,500$ and that the market price at the time and place of tender had fallen to $\$ 8,000$. If this seller is permitted to recover $\$ 2,000$ under section $2-708(1)$, he will be overcompensated by $\$ 1,500$, the amount by which the seller's costs. would have exceeded the market price. Although performance would only have brought $\$ 500$ profit, damages under section $2-708(1)$ would be $\$ 2,000$. White and Summers argue that if a buyer can establish that section 2-708(1) damages would overcompensate the seller in this way, the seller should have to measure damages under the cost plus overhead formula of section 2-708(2). Although they recognize that section 2-708(2) by its terms applies only if section 2-708(1) is "inadequate" to put the seller in as good a position as performance would have, and that in this situation the problem is that section 2-708(1) is more than adequate, they assert that the general just compensation principle of the Code ${ }^{180}$ should be applied in this situation to overcome any difficulties with the language of section $2-708(2) .181$

On the other hand, Professors Goetz and Scott would permit a seller to recover the difference between market price and contract price under section 2-708(1) even when the market price is less than the variable cost of production. ${ }^{182}$ They assert that the seller would

179 J. Whrte \& R. Summers, supra note 1, §7-12.

180 "The remedies provided by this Act shall be liberally administered to the end that the aggrieved party may be put in as good a position as if the other party had fully performed ...." U.C.C. \$1-106.

$181 \mathrm{~J}$. WhIte \& R. Summers, supra note $1, \$ 7-12$; see also Childres \& Burgess, supra note 37, at 877-79. In Nobbs Chem., U.S.A., Inc. v. Koppers Co., 616 F.2d 212 (5th Cir. 1980), the court agreed with Professors White and Summers, refusing to award plaintiff seller damages under $\$ 2-708$ (1) because $\$ 2-708(2)$ was sufficient to put the aggrieved party in as good a position as if the other party had fully performed and "not in a better posture." Id. 215 . Cf. Jagger Bros. v. Technical Textile Co., 202 Pa. Super. 639, 198 A.2d 888 (1964) (permitting a seller who had reasonably ceased production after the buyer's breach to measure damages under $\$ 2-708(1)$; although the buyer objected to this damage award, he did not offer to prove that the award would overcompensate the seller).

182 Goetz \& Scott, supra note 108, at 355-56. 
not be overcompensated because if the market price did fall below the seller's costs; an economically rational seller..would procure equivalent goods on the market to perform the contract. In the previous example, for instance, Goetz and Scott would expect the seller to perform by buying goods on the market for $\$ 8,000$ rather than by spending $\$ 9,500$ to produce the goods himself. They as: sume that the seller would know of the low market price at the time he was'to begin production and that the substitute goods procured on the market would be acceptable to the buyer. Absent very standardized and fungible goods, however, it seems quite likely that the buyer would object. Remember the public outcry a few years ago when General Motors substituted substantially equivalent Chevrolet engines for some Oldsmobile engines. ${ }^{183}$ Even if the buyer would not object to receiving substitute goods, it is very possible that the seller would not have known about the lower price for substitute goods until well after the time for beginning production. Thus, it frequently. would be very difficult for the seller to predict prior to production that savings could be achieved by purchasing the goods on the market.

In short, the scenario envisaged by Goetz and Scott is not likely to occur frequently, and absent those unique circumstances, there is a considerable risk of overcompensation if a seller who has not completed production is permitted to recover market damages under section 2-708(1). I agree with White and Summers that in such a situation the buyer should be able to force the seller to measure damages under the lost profit formula of section 2-708(2). Because the present language of the Code makes it difficult to reach this result, ${ }^{184}$ I urge that the Code be revised to make it clear that the formula of section 2-708(2) is the only damage provision applicable to a seller who reasonably stops production. ${ }^{185}$

\section{Difficulties with the Formula of Section 2-708(2)}

Section 2-708(2) provides that a seller may recover "profit (including reasonable overhead)." This language suggests that a court, in awarding damages under this provision, needs to be concerned

183 See 1978 Consumen REP. 190-91.

184 See supra notes 180-81 and accompanying text.

185 A seller still could attempt to prove that he would have performed the contract by purchasing goods on the market rather than producing them himself, thus reducing his costs of production and commensurately increasing his profit. This, then, would be a matter of proof rather than an opportunity for the seller to escape to an inappropriate damage measure. 
about whether the proper amount of overhead was allocated to the breached contract in accordance with generally accepted accounting principles and whether overhead and profit were properly separated. These inquiries are irrelevant, however. If the objective is to determine the net return necessary to put the seller in the same position as performance, there is no need to distinguish between profit and overhead or to worry about whether overhead was properly allocated to the contract. It is only necessary to determine the difference between contract price and variable cost. These are the costs that would be incurred for the performance of the contract, but would not be incurred if the contract were never performed.

That it is unnecessary to think about overhead as a separate concept can be seen from the following example. Assume that the contract price is $\$ 5,000$, the total variable costs are $\$ 4,000$, and the seller claims that overhead would be $\$ 400$ and profit $\$ 600$. It would be useless for the buyer to argue that $\$ 200$ too much overhead had been allocated to this contract. As long as contract price and variable cost remain constant, the only effect of reducing the overhead allocated to the contract is to increase the profit. ${ }^{186}$ Overhead is nothing more than an accounting construct. ${ }^{187}$ The only purpose for allocating overhead to a contract is to ensure that the contract price is set high enough to cover not only the variable costs of performing the contract but also a ratable portion of the seller's fixed costs and, hopefully, some net return or profit. When a buyer pays the contract price, the difference between the contract price and the variable cost represents cash flow that is available for use in the seller's business, and it is for this difference between contract price and variable cost that the seller must be compensated when the buyer breaches. ${ }^{188}$ Possibly taking a hint from the comment to section $2-708(2),{ }^{189}$ many courts have measured damages under sec-

188 The point is demonstrable algebraically: contract price $=$ profit + overhead + variable cost. Subtracting variable cost from both sides of the equation produces: contract price - variable cost $=$ profit + overhead. Thus, if contract price and variable cost remain constant, a change in overhead can only produce a change in profit. 1967).

187 See, e.g., Vitex Mfg. Corp. v. Caribtex Corp., 377 F.2d 795, $799 \cdot(3 \mathrm{~d}$ Cir.

188 For a thorough discussion, see Childres \& Burgess, supra note 37 , at 841-60. Courts have recognized that "overhead," to the extent it represents fixed costs, is not a cost that should be deducted but an amount that the seller should recover. E.g., Vitex Mfg. Corp. v. Caribtex Corp., 377 F.2d 795 (3d Cir. 1967); Coast Trading Co. v. Parmac, Inc., 21 Wash. App. 896, 587 P.2d 1071 (1978).

189 "The normal measure . . . would be list price less cost to the dealer or list price less manufacturing cost to the manufacturer." U.C.C. $\$ 2-708(2)$ comment 2. 
tion 2-708(2) by the difference between contract price and variable cost, thus avoiding unnecessary squabbles about overhead..$^{190}$ For clarity, however, the formula should be revised to eliminate the terms profit and overhead, instead providing for recovery of the difference between contract price and the total variable costs of performance.

Although there is no need to distinguish between profit and overhead, it is very important that the variable cost figure be accurate when measuring damages under the contract price less variable cost formula. If the variable cost is understated, then the seller will be overcompensated because part of the recovery that the seller will receive actually would have been consumed by variable costs of production. ${ }^{191}$ Most of the decisions to date have permitted the seller to prove profit plus overhead under section 2-708(2) by the difference between contract price and "average variable cost"-an historical cost figure based upon the average cost of producing similar units over a period of time..$^{192}$ A more accurate cost figure would be marginal cost, which is the actual additional cost incurred to produce a specific additional unit of output. When the seller is operating at a level of output where its marginal costs are rising, those marginal costs exceed the historical average variable costs. ${ }^{193}$ In these circumstances, the risk of overcompensation be-

190 See, e.g., Nederlandse Draadindustrie NDI B.V. v. Grand Pre-Stressed Corp., 466 F. Supp. 846 (E.D.N.Y.), aff'd mem., 614 F.2d 1289 (2nd Cir. 1979); Holiday Mfg. Co. v. B.A.S.F. Systems, Inc., 380 F. Supp. 1096 (D. Neb. 1974); Jericho Sash and Door Co. v. Building Erectors, Inc., 362 Mass. 871, 286 N.E.2d 343 (1972); E-Z Roll Hardware Mfg. Co. v. H \& H Prods. \& Finishing Corp., 4 U.C.C. Rep. Serv. (Callaghan) 1045 (N.Y. App. Div. 1968); Industrial Circuits Co. v. Terminal Communications, Inc., 26 N.C. App. 536, 216 S.E.2d 919 (1975); Coast Trading Co. v. Parmac, Inc., 21 Wash. App. 896, 587 P.2d 1071 (1978).

191 This focus on the problem of underestimating variable costs may give some meaning to the term "reasonable" that the drafters used in connection with overhead. While it makes no sense to worry about whether too much overhead was allocated. to a contract, it is very important to be sure that "overhead" does not include amounts that are allocable to variable costs.

192 See, e.g., American Metal Climax, Inc. v. Essex Int'l, Inc., 16 U.C.C. Rep. Serv. (Callaghan) 101 (S.D.N.Y. 1974). See generally R. Nondstrom, supra note $140, \S 177$, at $538(1970)$.

193 There are production levels at which the seller's marginal cost may be decreasing, remaining constant, or increasing very slowly. See supra notes 129-31. The average variable cost, then, may be higher than the marginal cost. In these cases, awarding damages as the contract price minus the average variable cost may undercompensate the seller. Because the Code's policy is to put the aggrieved party in as good a position as performance would have done, see U.C.C. $\$ 1-106$, marginal cost figures are the best data to use in computing damages under $\$ 2-708(2)$. But see infra notes 195-97 and accompanying text (evidentiary problems of marginal cost data). 
comes significant when average variable cost is used to prove the seller's loss. ${ }^{194}$ The problem is illustrated by the accompanying graph.

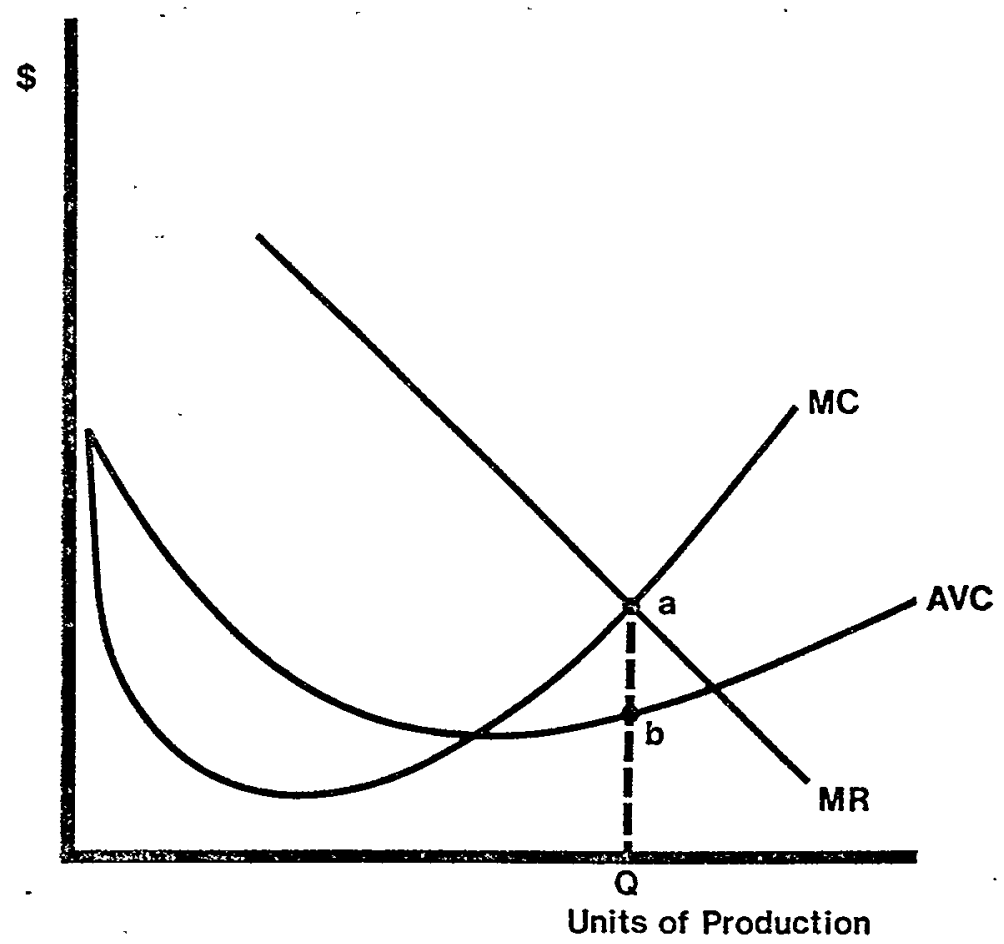

If the seller is producing at the profit-maximizing level of output $Q$ (where marginal cost (MC) equals marginal revenue (MR)), awarding damages measured by the contract price less average variable cost (AVC) will overcompensate the seller by the difference between his true marginal cost at output $Q$ (point a) and his average variable cost at that output (point b).

This risk of overcompensation by using average variable cost data suggests that the seller should be required to prove the more

194 In at least one case, a court was sensitive to the risk of overcompensation created by inaccurate cost estimates. In Timber Access Indus. Co. v. U.S. PlywoodChampion Papers, Inc., 263 Or. 509, 503 P.2d 482 (1972), the court recalculated damages based upon evidence that the seller's actual costs of performance would: have been higher than the seller had claimed. The problem was not the difference between average and marginal costs, however; it was that the seller had incorrectly claimed that an advance payment he has made would reduce his actual costs of production. Id. at 527, 503 P.2d 490-91. 
accurate marginal costs of production. ${ }^{195}$ The problem with insisting on proof of marginal cost, however, is that marginal cost data is much more difficult and costly to obtain than is average cost data. ${ }^{196}$ Insisting in all circumstances on marginal cost data may create a significant barrier to recovery by sellers and result in considerable undercompensation. The best solution is to continue allowing a seller to use average variable cost data to establish a prima facie case, but to permit a buyer to rebut that proof by introducing evidence of the seller's increasing marginal cost. ${ }^{197}$

\section{B. Market Damages Under Section 2-708(1)}

The market damage provision of section 2-708(1) is a remedy of very limited utility. There seem to be only three circumstances in which section 2-708(1) provides the appropriate remedy for an aggrieved seller: when a non-lost-volume seller resells but does not satisfy the criteria for recovery of contract price less resale price under section 2-706; ${ }^{198}$ when a seller attempts to recover the price under section 2-709 and is held not to be entitled to the price, ${ }^{199}$

105 Speidel and Clay have made the broader argument that a seller normally should recover nothing for "overhead" because most sellers will be operating at a point at which their per unit average variable costs are increasing more than their per unit average fixed costs (overhead) are declining. Thus the loss in not being able to spread overhead to an additional sale normally will be exceeded by the variable cost savings. Speidel \& Clay, supra note 160 , at 711 . Their thesis is Hawed, however, because the relationship they assume between per unit average variable costs and average fixed costs is not necessarily normal for most sellers and because they ignore the importance of marginal costs. See KroNMAN \& POSNER, ThE Economics of Contract LAW 225-28 (1979). The more accurate proposition is that profit plus overhead should be measured by the difference between contract price and marginal cost.

196 See supra text following note 130. This difficulty of proof is not so great if the seller is a retailer of an item with a large price like an automobile or a boat. For such a seller, the major element of marginal cost is the acquisition cost of the item. The seller probably would have an invoice from the manufacturer or wholesaler to establish that cost. Cf. Neri v. Retail Marine Corp., 30 N.Y.2d 393, 285 N.E.2d 311, 334 N.Y.S.2d 165 (1972) (seller able to prove, without contradiction, his profit expected on the sale of a boat).

197 See Goetz \& Scott, supra note 108, at 365-68. The authors argue that permitting the seller to establish a prima facie case by use of average variable cost will create an efficient model of litigation. It will then be the buyer, who has the incentive to challenge the seller's cost data, who will choose whether to devote the additional resources necessary to establish marginal cost. Liberal discovery rules should enable the buyer to obtain marginal cost data without much more difficulty than the seller would experience.

198 See U.C.C. $\$ 2-706$ comment 2. Concerning the possibility that such a seller should be entitled to use $\$ 2-708(2)$, see supra notes 169-76 and accompanying text.

190 U.C.C. $\$ 2-709$ (3) provides that a seller who is held not entitled to the price may recover under $\$ 2-708$. See, e.g., Publicker Indus., Inc. v. Roman Ceramics Corp., 603 F.2d 1065 (3d Cir. 1979). 
and when a seller who has completed goods on hand decides not to resell them. ${ }^{200}$ Despite its limited role, ${ }^{201}$ this market damage provision is essential in these few circumstances. ${ }^{202}$

One aspect of this provision that does need to be re-examined is the time at which market damages are measured. Section 2-708(1) provides that a seller's market damages are measured by the "market price at the time and place for tender." Essentially, this requires measuring market damages at the time specified in the contract for delivery of the goods to the buyer. ${ }^{203}$ It will be recalled that the analogous buyers' remedy provides for measuring a buyer's market damages at a different time: the "time when the buyer learned of the breach." 204 The buyers' damages language has led to some difficulty in determining when to measure the market in the case of an anticipatory repudiation. ${ }^{205}$ I have argued that a buyer's market damages after an anticipatory repudiation normally should be measured by the market price at the end of the commercially reasonable time that the buyer has in which to await performance by the seller. Measuring market damages at that time is consistent with the Code's dual policies of encouraging cover and permitting the aggrieved party to await performance for a reasonable time, but no longer. ${ }^{208}$

200 For a general discussion of the circumstances in which $\$ 2-708(1)$ might be applicable, in addition to an argument for the repeal of the section, see Childres \& Burgess, stupra note 37 , at 880-84.

201 A few courts have asserted that this remedy should be extended further, allowing a seller to measure damages under $\$ 2-708(1)$ in two other situations. First, a seller who has not begun production might seek market damages under $\$ 2-708(1)$, rather than the component damages provided in $\$ 2-708(2)$, if the market price was less than the cost of production. Second, a non-lost-volume seller who has resold completed goods might want to have damages measured under $\$ 2-708(1)$, if the market price was less than the resale price. I have already argued, however, that in both of these instances $\$ 2-708(1)$ is an inappropriate damage measure because it would result in overcompensating the seller. See supra notes 90-100 \& 180-85 and accompanying text.

202 See supra notes 47-66 and accompanying text for a discussion, focusing on buyers' remedies, concerning the value of the market damage provisions of the Code. There probably will be relatively fewer circumstances in which a seller will seek market damages than those in which a buyer will seek market damages. It seems more likely that a buyer will choose not to cover after a seller's breach than that a seller with completed goods will choose not to resell after a buyer's breach. The seller already has the goods on hand that he is in the business of selling, whereas the buyer's needs for the goods may change. If the seller resells, 2-708 (1) should apply only if the seller fails to comply with the requirements of 2-706.

203 See J. WhITE \& R. SUMmers, supra note 1, $\$ 6-4,7-7$, at 226-30, 270.

204 U.C.C. $\$ 2-713(1)$.

205 See supra notes $67-89$ and accompanying text.

208 See supra notes $72-81$ and accompanying text. 
Although the language of the seller's market damage provision does not provide similar flexibility, many of the arguments for measuring a buyer's market damages in the event of an anticipatory repudiation at the end of a reasonable time for awaiting performance are equally applicable when a seller seeks market damages. ${ }^{207}$ The repudiation may occur a long time before the date of tender, particularly in a long-term installment contract. A seller who reasonably chooses to resell shortly after the repudiation should not have to assume the risk that market damages will be measured in a much later, and probably much higher, market if his resale does not conform to the requirements of section 2-706. ${ }^{208}$ Similarly, if a seller chooses not to resell the goods, the market damages should be measured in the market in which he most likely would have entered into a resale contract. This is more likely to be the market at a reasonable time after the repudiation than the market at the time of tender. ${ }^{209}$ Thus, in order to make sellers' and buyers' market damage provisions congruent, section 2-708(1) should be revised in the same manner that I have suggested section 2-713 be revised: in anticipatory repudiation situations, market damages should be measured at the end of the commercially reasonable time for awaiting performance or at the time that the seller actually cancels the contract, whichever is earlier. ${ }^{210}$ In the case of a present breach,

207 One difference is that, because of the language of $\$ 2-708(1)$, there is little risk that a court will measure damages at the date of repudiation unless the case comes to trial before the date for performance, in which case $\$ 2-723$ 's rule requiring that market damages be measured as of the date of repudiation comes into play. This problem is more acute in the case of buyers' damages. A number of cases have held that a buyer's market damages should be measured at the date of repudiation under the "time when the buyer learned of the breach" language in \$2-713. See supra note 67 and accompanying text. In either case, measuring damages at the date of repudiation is inconsistent with the aggrieved party's right to await performance for a commercially reasonable time, which should at least include sufficient time to enable the aggrieved party to make reasonable efforts to convince the repudiator to retract the repudiation. See supra notes 78-79 \& 83-87 and accompanying text.

208 Section 2-723, which provides that damages are to be measured as of the date of repudiation if the case comes to trial before the date for performance, alleviates this problem in some situations. Because of docket delays and delays in filing suit, however, $\$ 2-723$ applies only to a very small percentage of cases.

209 See J. WhITE \& R. Summens, supra note 1, $\$ 7-7$, at 270-71. The market price still should take account of the fact that the seller, although he might contract for resale shortly after the end of the reasonable time for awaiting performance, probably would contract for delivery at some future time. Thus, if there is any significant difference between the market price for spot sales and the price for future sales at the end of the commercially reasonable time, the price for future delivery normally should be used. See supra note 88 . 
however, the existing measure of market damages under section 2-708(1)-the time and place of tender-is adequate. ${ }^{211}$

\section{Summary and Suggestions for Revision}

The preceding pages have reviewed a number of serious diffculties with the sellers' remedy provisions of the Code. The Code provides inadequate guidance concerning which sellers are entitled to have their damages measured by the profit plus overhead formula of section 2-708(2). This has led to inadequate case law definitions of the lost volume seller. ${ }^{212}$ It also has created a risk that section 2-708(2) will be applied in inappropriate situations, such as to a seller with completed goods who is not a lost volume seller and who merely has failed to meet the criteria for recovery of contract price less resale price under section 2-706.213 Other serious problems arise because the literal formula of section 2-708(2) is inappropriate when applied to lost volume sellers ${ }^{214}$ and because the formula's use of the term "profit (including reasonable overhead)" encourages an entirely unnecessary, and potentially confusing, concentration on overhead as a separate item of damages. ${ }^{215}$ In addition, the present version of the Code does not clearly prohibit a seller who has actually resold from receiving a larger than compensatory recovery under section 2-708(1) based upon a market price lower than the actual resale price, ${ }^{216}$ nor does the present Code expressly state the consequences of a seller's unreasonable decision to stop or complete production. ${ }^{217}$ Finally, because section 2-708(1) measures a seller's market damages at the time of tender rather than at the time the seller learned of the breach, sellers' and buyers' market damages are measured inconsistently in the case of an anticipatory

211 The "time when the buyer learned of the breach" measure for buyers' damages in $\$ 2-713$ was intended, at least in part, to permit measuring damages after the date of tender when the buyer does not discover the breach until after tender, such as when the buyer discovers a defect in the goods after the date of tender. See J. WhItE \& R. SumMErs, supra note 1, \$6-7, at 244-46. There is little need for similar flexibility in measuring damages for a buyer's present breach (such as refusal to accept delivery) because a seller would probably discover such a breach immediately. Thus, measuring damages in the market at the time of tender normally will produce an acceptable result because the market at tender probably would be the market in which the seller would have resold.

212 See supra notes $114-20$ and accompanying text.

213 Such a seller should be remitted to the market damage recovery of \$2-708(1). See supra notes 169-78 and accompanying text.

214 The courts thus have been forced to adopt strained constructions of the statutory language in order to achieve reasonable results. See stpra notes 138-46 and accompanying text.

215 See supra notes $186-90$ and accompanying text. 210 See supra notes $90-100$ and accompanying text. 217 See supra notes 161-68 and accompanying text. 
repudiation. Sellers' damages are measured later than they should be in order to encourage the most efficient behavior. ${ }^{218}$

Thus, section 2-708 should be revised in order to ensure that appropriate remedies are provided in as many cases as possible and to achieve more fully the drafters' goal of providing a more certain and accessible law of sales. I suggest that the Permanent Editorial Board consider the following revisions. First, the reference to profit and overhead in section 2-708(2) should be eliminated and replaced with a basic measure of contract price less total variable cost. This will eliminate unnecessary concentration on overhead as a separate item of damage.

Second, there should be separate subsections applicable to the lost volume seller and to the components seller or jobber who reasonably stops work. Having separate subsections is the best way to accommodate these two different situations. In order to prevent possibly overbroad judicial definitions of a lost volume seller, the statute itself should establish a definition containing at least two elements: a requirement that the seller demonstrate that he had the capacity to make an additional sale, and a requirement that the seller show that he probably would have made a sale to the actual resale buyer even if the original buyer had not breached. ${ }^{219}$ The formula applicable to the lost volume seller might read as follows: unpaid contract price ${ }^{220}$ less total variable costs, plus incidental damages, plus wasted costs reasonably incurred, less proceeds of any resale not involving lost volume, and less the market value of goods retained. The "wasted costs" provision would make it clear that the seller could recover for any costs reasonably incurred for the sale that could not be recouped on resale; ${ }^{221}$ the "proceeds" portion

218 See supra notes 203-11 and accompanying text.

210 Professor Harris posits a third separate condition to lost volume status: that the resale buyer would have been solicited by the seller had there been no breach. See supra note 120 and accompanying text. This condition seems sufficiently subsumed under the second criterion that I suggest (that an additional sale probably would have been made to the actual resale buyer); thus, it need not be mentioned separately in the statutory definition of a lost volume seller. If necessary, a comment could focus attention on any significant problems that might arise in this regard, such as the possibility that the seller would have engaged in extraordinary attempts to resell the goods after breach, using special advertising or soliciting buyers whom the seller otherwise would not have contacted.

220 Thus, there is no need in the suggested formula for the separate credit for payments made that appears in the current version of $\$ 2-708(2)$.

221 Examples of possible "wasted costs" would include the cost of acquiring accessories that could not be resold to the second buyer or another normal purchaser, costs of preparing the goods for delivery that had to be incurred again prior to the second sale, and sales commissions paid on the initial sale to the extent they were not recoverable after breach. 
of the suggested formula would accommodate the possibility that some parts of the goods intended for sale to the buyer might not be resold or might have to be resold at a loss for salvage or in some other type of sale that would not involve lost volume. ${ }^{222}$

With respect to the components seller or jobber, the Permanent Editorial Board should consider a separate subsection that would apply to all sellers who reasonably cease production or decide not to acquire goods intended for resale to the breaching buyer. The formula applicable to such sellers might be: unpaid contract price less total variable costs, plus incidental damages, plus costs reasonably incurred, less proceeds of resale, and less the market value of goods retained.223 Having a separate formula for components sellers and jobbers will help assure the accurate computation of damages for such sellers; in addition, it will eliminate the possibility that a seller who never began production would be able to recover under the market damage formula of section 2-708(1). As has previously been shown, recovery under section $2-708(1)$ in such a situation would result in overcompensating the seller if the market price was less than the costs of production would have been. ${ }^{224}$

Third, section 2-704 should be revised to make it clear that a seller who unreasonably stops or completes production after a breach or repudiation cannot recover damages greater than the seller would have been entitled to recover had he acted reasonably.225 Fourth, the basic market damage measure of section 2-708(1) should be revised to provide alternative times for measuring damages. Damages should be measured at the time of tender in the event of a present breach, but after an anticipatory repudiation market damages should be measured at the end of the commercially reasonable time for awaiting performance or at the time that the seller actually cancels

222 The breaching buyer is entitled to credit for the value or proceeds of resale of such goods. See supra notes 147-50 and accompanying text.

223 Theoretically, it would be possible to use the same formula for both the lost volume seller and the components seller or jobber. One possible way to state such a unified formula would be: unpaid contract price less expenses saved, plus incidental damages, less proceeds of any resale not involving lost volume, and/or less the market value of goods retained. In this formula, "expenses saved" would be total variable costs less any "wasted costs" reasonably incurred. It would be diffcult, however, to insure that this unified formula was applied accurately in both the lost volume and component seller situations. It is preferable, therefore, to establish different formulae for these two different situations.

224 See supra notes 180-85 and accompanying text.

225 The comment should mention the possibility that a seller who reasonably stopped production might have been a lost volume seller had production been completed. If that was the case, damages should be measured under the lost volume seller provision rather than the market damage provision of $\$ 2-708(1)$. See supro note 167-68 and accompanying text. 
the contract, whichever is earlier. ${ }^{228}$ Finally, to avoid overcompensating a seller who has not suffered lost volume, the Code should be revised to make it clear that a seller who has actually resold may not measure market damages under section 2-708(1) based on a market price that is less than the actual resale price. ${ }^{227}$

I do not assert that the proposed revisions will make the sellers' remedy provisions of the Code more simple, but then one of the major faults of the present Code is that these provisions are too simple. In section 2-708(2), particularly, the drafters attempted to do too much by having a single, relatively short provision that attempts to cover as widely diverse situations as those of the lost volume seller and the components seller. . If the revisions suggested in this Article are adopted, the sellers' remedy provisions of the Code will be more detailed than they presently are, giving courts and attorneys significantly more guidance concerning the way damages should be measured in various situations.

\section{CoNCLUSION}

This Article has reviewed various interpretive and policy difficulties with the remedy provisions of the sales article of the Uniform Commercial Code and has suggested possible revisions of the Code that would alleviate some of the problems discussed. Two of those recommendations, focusing on provisions that have created significant problems for courts and attorneys, are of major importance and deserve reiteration. The first of these recommendations is that the market damages provisions of sections 2-708(1) and 2-713 be revised to provide that, in cases of anticipatory repudiation, market damages will be measured at the end of the commercially reasonable time for awaiting performance after repudiation or at the time that the nonrepudiating party actually cancels the contract, whichever is earlier. This change would help ensure a market damage measure that is consonant with the Code's policy of permitting an aggrieved party to await performance only for a reasonable time after repudiation rather than until the date of performance. ${ }^{228}$

The other significant group of recommendations concerns section 2-708(2). This section has been applied in two vastly different situations-that of the lost volume seller and that of the components seller or jobber who reasonably stops work upon learn-

226 See supra notes 207-11 and accompanying text.

227 See supra notes 90-100 and accompanying text.

228 See U.C.C. \$2-610; supra notes $67-89$ and accompanying text. 
ing of a breach or repudiation. The major suggestion offered here is that separate statutory remedy provisions be created for the lost volume seller and for the components seller or jobber. In this way, courts will be given more precise guidance concerning the appropriate measure of damages in each situation. Furthermore, the Code should include a statutory definition of the lost volume seller to help assure that non-lost-volume sellers are not overcompensated by being permitted to have their damages measured under the lostvolume-seller damage formula. ${ }^{229}$ In addition to these primary recommendations, I have suggested a number of other changes that would eliminate other interpretive difficulties arising in connection with the remedy provisions of article 2 . The ultimate objective of all of these recommendations is to make the Code's remedy pro: visions more accurately fulfill the traditional "just compensation" principle of contract damages-to place the aggrieved party in as good a position as performance would have, but not in a better position.230

Although the revisions of the sales remedy provisions that I have suggested are significant in themselves, I must again emphasize that such revisions should be considered in the context of an overall review of article 2. Piecemeal revisions of specific sections of the Code run the risk of substantially undermining the goal of uniformity. Many state legislatures may well be less willing to adopt revisions of only one part of article 2 than they would be to consider an overall revision of the article. Moreover, although the remedy provisions of article 2 are the ones most seriously in need of revision, there are sufficient problems with other portions of article 2 to justify a complete review at this time. ${ }^{231}$ It is my hope

229 See supra notes 212-24 and accompanying text.

230 The "just compensation" principle is reiterated in $\$ 1-106$ of the Code. See also Restatement (SECOND) of Contracts $\$ 344$ \& comment a (student ed. 1981).

231 A few obvious candidates for reconsideration and revision come to mind. One is $\$ 2-207$, in which the Code drafters made an innovative but not entirely successful attempt to provide rules for establishing the terms of a contract when the writings of the parties (such as purchase orders and acknowledgement forms) do not agree with respect to all terms. The case law and commentary on that provision indicate that serious problems remain, and it is fair to say that the problem of the battle of the forms has not yet been solved. See, e.g., Idaho Power Co. v. Westinghouse Elec. Corp., 596 F.2d 924 (9th Cir. 1979); Roto-Lith, Ltd. v. F.P. Bartlett \& Co., 297 F.2d 497 (1st Cir. 1962). See generally Duesenberg, Contract Creation: The Continuing Struggle with Additional and Different Terms Under Uniform Commercial Code Section 2-207, 34 Bus. LAw. 1477 (1979); Murray, Section 2-207 of the Uniform Commercial Code: Another Word About Incipient Unconscionability, 39 U. PrTr. L. REv. 597 (1978).

Also troublesome has been the concept that promises, affirmations, and descriptions concerning goods become express warranties under $\$ 2-313$ only if they 
that this Article will contribute to the initiation of a review process that ultimately will produce a salutary overall revision of article 2.

become "part of the basis of the bargain." "Basis of the bargain" is a new concept nowhere defined in the Code, and particularly sharp disagreement has arisen concerning the extent to which, under this new language, reliance by the buyer is still necessary or relevant to the creation of an express warranty. Compare Stang $v$. Hertz Corp., 83 N.M. 217, 490 P.2d 475 (Ct. App. 1971), rev'd on other grounds, 83 N.M. 730, 497 P.2d 732 (1972) with Bigelow v. Agway, 506 F.2d 551 (2d Cir. 1074). See generally Note, 34 U. PrrT. L. Rev. 145 (1972).

In addition to these and other instances in which specific provisions of article 2 might be improved, there are some questions that permeate the entire article and could usefully be considered in any review process. The most important of these pervasive questions involves the treatment of consumers: Should there be more explicit recognition in the Code of the different status of consumers and professionals, and should more provisions explicitly impose different standards of conduct on consumers and professionals? Another pervasive issue is one of scope: Should the coverage of article 2, particularly including its warranty provisions, be expanded explicitly to include leases of goods? 